\title{
Achieving Efficiency Through Collusion: A Market Failure Defense to Horizontal Price-Fixing
}

\author{
Christopher R. Leshe $\uparrow$
}

The inherent tension between Adam Smith's invisible hand and governmental regulation of the economy has long been noted, especially in regard to antitrust law. In this Comment, the author challenges the modern application of the Sherman Act in the specific context of horizontal price-fixing, casting the courts' treatment of such conduct in some cases as an outdated and counterproductive infringement on the free market. As a precursor to this challenge, the author proposes that efficiency, not competition, must be accepted as the relevant objective of the Sherman Act; the courts' tradition of favoring competition over efficiency, once arguably prudent, has become overly cautious in light of major developments in economic theory and the increased sophistication of the judiciary. To further the Sherman Act's goal of an efficient marketplace, the author calls on the courts to adopt the economic theory of the "second best." According to this theory, collusion among competitors, when occurring in the context of multiple market failures, is often best left alone. In such situations, the various failures may cancel each other out so that judicial deference to the invisible hand, not judicial intervention, maximizes efficiency.

[B]y directing that industry in such a manner as its produce may be of the greatest value, he intends only his own gain, and he is ... led by an invisible hand to promote an end which was no part of his intention. . . . By pursuing his own interest he frequently promotes that of the society more effectually than when he really intends to promote it.

-Adam Smith, The Wealth of Nations ${ }^{1}$

Over two centuries ago, Adam Smith developed the concept of the invisible hand whereby individuals, acting in their own self-imterest, max-

$\dagger$ B.A. 1986, University of California, Los Angeles; M.P.P. 1988, Harvard University, John F. Kennedy School of Government; I.D. candidate 1993, Boalt Hall School of Law, University of California, Berkeley.

1. I Adam Smith, an Inquiry into the Nature and Causes of the Wealth of NAtions 456 (R.H. Campbell et al. eds., Oxford Univ. Press 1976) (1776). 
imize economic and social efficiency. One century ago, Congress worried that the invisible hand might be arthritic and passed the Sherman Act. ${ }^{2}$ When a free market could not achieve efficiency, antitrust laws would. This Comment discusses the treatment of horizontal price-fixing ${ }^{3}$ under the Sherman Act and concludes that in soine cases, antitrust laws improperly interfere with the invisible hand. Specifically, horizontal price-fixing is sometimes efficient and should not be uniformly condemned.

This Comment is organized in four Parts. Part I of the Comment argues that, while there are several objectives advanced for the Sherman Act, efficiency is the relevant goal for antitrust analysis. There are two types of efficiency: productive and allocative. Competition in the marketplace is another goal of antitrust; it is often used as a proxy for effciency. However, sometimes the goals of efficiency and competition are in conflict. When they are, courts emphasize competition at the expense of efficiency.

Part II presents the economic theory of the second best. In some circumstances, competition inhibits efficiency. The competitive model is based on a series of assumptions. Unmet assumptions are market failures. In general, the government should try to correct a market failure. However, the theory of the second best demonstrates that when there are multiple market failures, the best solution may be government maction. Antitrust laws are one government tool to correct the market failure of collusion among coinpetitors. According to the theory of the second best, when other market failures are also present the various failures may cancel each other out, so that nonenforcement of antitrust laws maximizes efficiency.

Part III apphies the theory of the second best to collusion in inarkets with high negative externalities. A negative externality exists whenever the shelf price of a product is less than the total cost of consumption. Examples and economic analysis will show that for some products with high negative externalities, efficiency is achieved by nonenforcement of antitrust laws.

Part IV discusses potential difficulties in applying a market failure defense to antitrust enforcement. But these difficulties are easily surmounted and often addressed in other areas of antitrust. Given that the primary goal of antitrust is efficiency, courts should allow a market fail-

2. Sherman Antitrust Act, ch. 647, 26 Stat. 209 (1890) (codified as amended at 15 U.S.C. $\S \S 1-7$ (1988 \& Supp. III 1991)).

3. Horizontal price-fixing exists whenever competitors agree to raise, depress, or stabilize prices. The archetype is when sellers set a minimum price for a given product. See infra text accompanying notes $17-24,40-41$. This Cominent does not specifically discuss vertical price-fixing, which exists when a manufacturer and wholesaler, or wholesaler and retailer, agree to restrain price fluctuations. 
ure defense as an argument that certain price-fixing arrangements are efficient.

\section{I \\ ANTITRUST AND COMPETITION}

\section{A. Judicial Standards for Ensuring Competition}

Before examining the underlying goals of antitrust laws, it is helpful to describe the tests that the Supreme Court uses to evaluate alleged Sherman Act violations. Section One of the Sherman Act provides that "[e]very contract, combination in the form of trust or otherwise, or conspiracy, in restraint of trade or commerce among the several States, or with foreign nations, is declared to be illegal." 4 The Supreme Court initially interpreted the Sherman Act hiterally and held that "every" meant just that. ${ }^{5}$ Consequently, any contract that restricted trade was illegal.

The Court soon abandoned this approach as impractical, recognizmg that all contracts restrict trade to some extent and that contracts are necessary in modern econoinies. In Standard Oil Co. v. United States, ${ }^{6}$ the Court held that the Sherman Act only invalidated those agreements which "unreasonably" restrain trade. ${ }^{7}$ The Court defined the term "unreasonable" by equating it with "anticompetitive." Consequently, the effect on competition soon becaine the primary, if not sole, focus in determining the reasonableness of a challenged trade restraint.

The Court devised two means of determining whether a contested restraint is anticompetitive: per se rules and the rule of reason. The per se rules of antitrust are black letter prohibitions on certain categories of trade restraints. If a restraint falls within a certain category it is considered unreasonable as a matter of law; courts do not consider the particular market conditions or give defendants an opportunity to justify their conduct. ${ }^{8}$ Justice Black explained the application and justification for per se illegality in Northern Pacific Railway Co. v. United States ${ }^{9}$ as follows:

[T] here are certain agreements or practices which because of their pernicious effect on competition and lack of any redeeming virtue are conclusively presumed to be unreasonable and therefore illegal without elaborate mquiry as to the precise harm they have caused or the business excuse for their use. This primciple of per se unreasonableness not only makes the type of restraints which

4. 15 U.S.C. $\S 1$ (Supp. III 1991).

5. United States v. Trans-Missouri Freight Ass'n, 166 U.S. 290, 312 (1897), overruled by Standard Oil Co. v. United States, 221 U.S. 1 (1911).

6. 221 U.S. 1 (1911).

7. Id. at $63-65$.

8. United States v. Socony-Vacuum Oil Co., 310 U.S. 150, $217-18$ (1940).

9. 356 U.S. 1 (1958). 
are proscribed by the Sherman Act more certain to the benefit of everyone concerned, but it also avoids the necessity for an incredibly complicated and prolonged economic investigation into the entire history of the industry involved, as well as related industries, in an effort to determine at large whether a particular restraint has been unreasonable-an inquiry so often wholly fruitless when undertaken. ${ }^{10}$

The primary justification for per se rules is that case-by-case analysis is unnecessary because the prohibited restraints are almost certainly anticompetitive. The Court claims that restraints are classified as per se violations "only after considerable experience" with that conduct. ${ }^{11}$ However, the Court acknowledges that per se rules may sometimes prohibit restraints of trade that are harmless, efficient, competitive, or otherwise net beneficial. ${ }^{12}$ This is the cost of administrative efficiency. ${ }^{13}$

The Court has labeled a variety of restraints as illegal per se. Group boycotts, ${ }^{14}$ tying arrangements, ${ }^{15}$ and agreements among businesses to divide markets ${ }^{16}$ are categories of trade restraints deemed as illegal per se. Horizontal price-fixing, however, is the epitome of a per se violation. ${ }^{17}$

The Court has included a broad range of activities under the umbrella of price-fixing. In United States v. Socony-Vacuum Oil Co., ${ }^{18}$ the Court defined price-fixing that is illegal per se as any "combination formed for the purpose and with the effect of raising, depressing, fixing, pegging, or stabilizing the price of a commodity in interstate or foreign commerce."19 In addition to condemning the setting of minimum prices, courts have also proscribed maximuin prices $^{20}$ and negotiable price

10. Id. at 5 .

11. United States v. Topco Assocs., Inc., 405 U.S. 596, 607-08 (1972).

12. See Catalano, Inc. v. Target Sales, Inc., 446 U.S. 643,649 (1980) ("[T] practice may turn out to be harmless in a particular set of circumstances will not prevent its being declared unlawful per se.").

13. See FTC v. Superior Court Trial Lawyers Ass'n, 493 U.S. 411, 430 (1990) ("The administrative efficiency interests in antitrust regulation are unusually compelling.").

14. Fashion Originators' Guild v. FTC, 312 U.S. 457, 467-68 (1941).

15. International Salt Co. v. United Statcs, 332 U.S. 392, 396 (1947); see infra note 33 and accompanying text.

16. United States v. Topco Assocs., Inc., 405 U.S. 596, 610-12 (1972). Markets can be divided by territory or by customers. Market division impedes competition because within a given territory or class of consumers, a supplier has an effective monopoly.

17. See United States v. Socony-Vacuum Oil Co., 310 U.S. 150 (1940), discussed infra text accompanying note 85 .

18. 310 U.S. 150 (1940).

19. Id. at 223.

20. See Arizona y. Maricopa County Medical Soc'y, 457 U.S. 332 (1982); Kiefer-Stewart Co. v. Joseph E. Seagram \& Sons, Inc., 340 U.S. 211 (1951), overruled on other grounds by Copperweld Corp. v. Independence Tube Corp., 467 U.S. 752 (1984). 
lists. ${ }^{21}$ Even voluntary price schedules are per se illegal. ${ }^{22}$ Finally, because prices and quantity are intimately linked, agreements which curtail production or sale are treated as price restraints. ${ }^{23}$ As with all per se violations of antitrust law, once a court determines that an arrangement constitutes price-fixing the inquiry is finished. Defendants cannot argue that the fixed price is reasonable. ${ }^{24}$

The second mechanism for determining whether a disputed restraint is "unreasonably" anticoinpetitive is the rule of reason. Rule of reason analysis governs the majority of antitrust conduct. ${ }^{25}$ In contrast to the perfunctory conclusions of per se rules, the rule of reason standard requires courts to examine the actual effects of the challenged conduct in each specific case and thus decide whether that conduct is anticompetitive. In Chicago Board of Trade v. United States, ${ }^{26}$ the Court proposed that to apply the rule of reason correctly,

the court inust ordinarily consider the facts peculiar to the business to which the restraint is applied; its condition before and after the restranit was imposed; the nature of the restranit and its effect, actual and probable. The history of the restraint, the evil believed to exist, the reason for adopting the particular reinedy, the purpose or end sought to be attained, are all relevant facts. ${ }^{27}$

The rule of reason exanimes, theoretically, only those factors that bear on competition. Courts should not give weight to noncompetitive factors. While the primary question is whether conduct is anticoinpetitive, the analysis also considers whether a restraint has countervailing procompetitive effects. A court may determine that the procompetitive benefits of a specific restranit outweigh its anticompetitive effects and, accordingly, allow it to survive the rule of reason. ${ }^{28}$

There lias been a general trend away from per se rules toward

21. Plymouth Dealers' Ass'n v. United States, 279 F.2d 128, 132 (9th Cir. 1960) (holding an automobile dealers' association's uniform price list in violation of the Sherman Act even though prices were "starting points" and actual prices may have been different).

22. See United States v. National Ass'n of Real Estate Bds., 339 U.S. 485, $488-89$ (1950) (holding that real estate brokers' voluntary adoption of the local real estate board's "standard rates of commission" was a price-fixing scheme).

23. Cf. General Leaseways, Inc. v. National Truck Leasing Ass'n, 744 F.2d 588 (7th Cir. 1984) (holding an agreement between a truck-leasing association and a member coinpany, which forbade meınbers from doing business outside of designated locations in violation of the Sherman Act).

24. See United States v. Trenton Potteries Co., 273 U.S. 392, 396-97 (1927).

25. Continental T.V., Inc. v. GTE Sylvania, Inc., 433 U.S. 36, 49 (1977).

26. 246 U.S. 231 (1918).

27. Id. at 238. The Court in Chicago Board of Trade did not speeifically mention market share as an element in rule of reason analysis. Subsequent cases, however, have held this to be an important eleinent under the rule of reason test. See Copperweld Corp. v. Independence Tube Corp., 467 U.S. 752, 768 (1984) (referring to the rule of reason as "an inquiry into market power and market structure designed to assess the combination's actual effect").

28. This Comment will argue that, in effect, the courts do give weight to noncompetitive factors but make great effort to couch their opinions in the language of competitiveness. 
greater application of the rule of reason. The judicial branch can decrease the reach of per se rules in two ways. First, it can decide that an entire category of conduct is no longer per se illegal. For example, vertical restraints ${ }^{29}$ were lield to be per se illegal for the first fifty years of the Sherman Act. ${ }^{30}$ In Continental T.V., Inc. v. GTE Sylvania, Inc., ${ }^{31}$ however, the Court overruled precedent and subjected nonprice vertical trade restrictions to the rule of reason. ${ }^{32}$ Tying arrangenents ${ }^{33}$ may be the next category of restraint removed from per se illegality to rule of reason status. In 1984 in Jefferson Parish Hospital District No. 2 v. Hyde, ${ }^{34}$ a five-member majority held that tymg arrangements are per se illegal. ${ }^{35}$ However, Justice O'Connor's four-meinber concurrence concluded that it was time "to abandon the 'per se' label and refocus the inquiry on the adverse econonnic effects, and the potential econoumic benefits, that the tie may liave."36 In a separate concurrence, Justices Brennan and Marshall argued that tying arrangements slould remain per se illegal. ${ }^{37}$ With their departure from the Court, the possibility exists that either or both of their replaceunents inay join the O'Connor camp.

Second, the Court can manipulate standards to remove the per se label froun certain conduct. For example, the Court can still hold that horizontal price-fixing is per se illegal but redefine what constitutes horizontal price-fixing so that the term encompasses fewer acts. A demonstrative case is Monsanto Co. v. Spray-Rite Service Corp., ${ }^{38}$ in which the Supreme Court adopted higher evidentiary standards to prove concerted action while reaffirming the per se illegality of such conduct. ${ }^{39}$

In limiting the reach of the per se rule through reclassification and

29. Vertical restraints exist when there is collusion between a manufacturer and wholesaler or between a wholesaler and retailer.

30. See United States v. Arnold, Schwinn \& Co., 388 U.S. 365, $372-74$ (1967), overruled by Continental T.V., Inc. v. GTE Sylvania, Inc., 433 U.S. 36 (1977).

31. 433 U.S. 36 (1977) (overruling Schwinn, and applying the rule of reason to a restrictive franchise agreenient between manufacturers and retailers that barred retailers from selling franchised products outside a specific location).

32. Id. at 57-59.

33. A tying arrangeinent exists when a seller with market power in one product (called the tying product) requires that consuniers purchase a second product (called the tied product) in order to purchase the tying product.

34. 466 U.S. 2 (1984).

35. Id. at 9-10. It should be noted that the current standard for tying arrangeinents is actually a "quasi per se rule" because plaintiffs nuust show that defendants have "appreciable economic power" in the nuarket for the tying product. Eastman Kodak Co. v. Image Technical Servs., Inc., 112 S. Ct. 2072, 2079 (1992).

36. 466 U.S. at 35 (O'Connor, J., concurring in the judgnent). In the Court's most recent tying arrangement case, Eastman Kodak, neither the majority nor the dissent challenged the tacit assumption of application of the per se rule to tying arrangeinents. However, the case concerned the standard for sunimary judgment and there was no need to explicitly address the standard for ultiniate adjudication.

37. Id. at 32 (Brennan, J., concurring).

38. 465 U.S. 752 (1984).

39. Id. at 761,763 . 
looser standards, the Court has expanded the rule of reason. The Sherman Act has evolved from a canon that forbade almost all contracts to a prescription that requires the judiciary to investigate the purposes and economic effects of most challenged contracts.

While the Court has chipped away at the per se doctrine in general, it has also indicated that horizontal price-fixing is the one violation that will remain subject to per se analysis. ${ }^{40}$ This stance is based on the widespread behef that horizontal price-fixing is necessarily anticoinpetitive and inefficient. ${ }^{41}$ Part of the reason that price-fixing will remain subject to per se treatinent may be pure entrenchment. ${ }^{42}$ The Court has steadfastly held that horizontal price-fixing is per se illegal since the inception of the rule of reason. The Court's official rationale for refusing to reconsider this characterization is that Congress, not the courts, should initiate these changes. ${ }^{43}$ This argument is disingenuous for two reasons. First, the Supreme Court developed the entire per se rule/rule of reason dichotomy from whole cloth, with no guidance from Congress. Second, the Court has removed other categories of conduct (for example, vertical nonprice restraints) from per se treatment without congressional approval, let alone mandate. ${ }^{44}$ The basic justifications for applying the per se rule to horizontal price-fixing reinain unexamined despite changes in economic theory and the increasing sophistication of economic analyses.

\section{B. The Primary Purpose of Antitrust Is to Maximize Efficiency}

Congressional intent is a difficult inquiry in general. The Sherman Act is no exception. Although Section One of the Sherman Act has just one sentence of text, this sentence has generated volumes of scholarly debate over the objectives of its drafters. This Section of the Comment discusses the possible objectives of antitrust law and concludes that they are all subsuined by a single criterion: efficiency. Thus, courts should interpret the Sherman Act in a way that maximizes efficiency.

40. See Donald Dewey, Economists and Antitrust: The Circular Road, 35 ANTITRUST BULL. 349,370 (1990). Discussion of price-fixing is particularly topical within antitrust, given that, during the 1980s, price-fixing cases comprised the vast majority of Department of Justice antitrust enforcement actions. Milton HaNDler et al., CASES AND MATERIals on Trade Regulation 105 (3d ed. 1990).

41. In 1989, a blue ribbon ABA Task Force concluded that "[v]irtually universal agreement exists that price-fixing among competitors ... should be prevented." Report of the American Bar Association Section of Antitrust Law Task Force on the Antitrust Division of the U.S. Department of Justice 19-20 (1989), quoted in HANDLER ET AL., supra note 40, at 106.

42. See Jefferson Parish Hosp. Dist. No. 2 v. Hyde, 466 U.S. 2, 9 (1984) ("It is far too late in the history of our antitrust jurisprudence to question the proposition that certain tying arrangements ... are unreasonable "per se" ").

43. See United States v. Topco Assocs., Inc., 405 U.S. 596, 609 n.10 (1972) (noting that, if Congress does not like the Court's per se rules, Congress is frec to change them).

44. See supra notes $29-37$ and accompanying text. 
One school of thought, which I shall call the Consumer Protection School, holds that antitrust laws exist solely to prevent consumers from being gouged by monopolists with the power to charge exorbitant prices. To these theorists, antitrust laws are designed to dimimish wealth transfers from consumers to big business. According to this school of thought, the legislature enacted the Sherman Act and its progeny ${ }^{45}$ to protect consumers by preventing overconcentration of business power within any given industry. The Consumer Protection School finds support in Supreine Court cases that suggest the Sherman Act was intended to serve the interests of the consumer. ${ }^{46}$ Busmess concentration, especially when it reaches the point of monopoly, is seen as inimical to the ability of consumers to obtain products at reasonable prices. ${ }^{47}$

Alternatively, the so-called Chicago School has identified efficiency as the primary objective of the Sherman Act. ${ }^{48}$ Under the leadership of professors-turned-judges Bork and Posner, the Chicago School theorists believe that the evil of monopoly and other restraints im trade is that they cause inefficiency. ${ }^{49}$ The Sherman Act was intended, it is argued, as a means to eliminate these inefficiencies. The Chicago School gained greater influence during the 1980s as its adlierents took "control of the federal enforcement agencies, and [became] increasingly influential in the courts."50 The Supreine Court lias cited the Chicago School with approval in most modern antitrust cases. ${ }^{51}$ With the rise of the Clicago School, "[t]lle current orthodoxy is that the sole goal of antitrust is economic efficiency." 52

The Chicago and Consuiner Protection Schools are usually consistent because the efficiency-based standard subsuines the consuiner protection objective. As Judge Easterbrook notes, "In the long run consumers gain most from a policy that empliasizes allocative and pro-

45. Clayton Antitrust Act, 38 Stat. 730 (1914) (codified as amended at 15 U.S.C. $\S \S 12-27$ (1988 \& Supp. III 1991)).

46. See, e.g., Jefferson Parish, 466 U.S. at 15 (noting that the Sherman Act "was especially intended to serve" consumers' interests).

47. This Coinment argues that an efficiency standard guarantees reasonable prices. An efficient price can never be unfair because consuners are not charged more than it costs to produce the good.

48. See Joe Sims \& Robert H. Lande, The End of Antitrust-Or a New Beginning?, 31 ANTITRUST BULL. 301, 316 (1986) (noting that with the rise of the Chicago Sehool, "[t]he current orthodoxy is that the sole goal of antitrust is economic efficiency"); Robert E. Taylor, $A$ Talk with Antitrust Chief William Baxter, WALl ST. J., Mar. 4, 1982, at 28.

49. For an economic discussion of how inonopoly causes inefficiency, see RoBERT H. BORK, The ANTtrRust Paradox 98-101 (1978).

50. Sims \& Lande, supra note 48 , at 306.

51. See, e.g., Reiter v. Sonocone Corp., 442 U.S. 330, 343 (1979) (observing that the original congressional debates on the Sherman Act "suggest that Congress designed the Sherman Act as a 'consumer welfare prescription' ") (quoting BoRK, supra note 49, at 66).

52. Sims \& Lande, supra note 48, at 316; see Taylor, supra note 48, at 28. 
ductive efficiency."53 By minimizing cost and maximizing output, an efficiency standard insures that consumers receive their optimal mix of goods. This thinking is consistent with well-estabhished economic theory. After all, the Sherman Act "is based on America's capitalist traditions, which rely on the 'invisible hand' of impersonal market forces to allocate resources efficiently and, thus, to maximize the [consumer] economic welfare of society." 54 Because efficiency is the maximization of social utility, the Chicago School's standard is often called the "consumer welfare" standard. Thus, the efficiency standard is best for society and for consuiners.

An alternative school of thought suggests that efficiency should not be the sole objective of antitrust. ${ }^{55}$ Some theorists argue that Congress, in adopting the Sherman Act, could not have been overly concerned with efficiency because the economic concept had not yet been developed. ${ }^{56}$ As one theorist explained, "It seems doubtful whether Congress gave much, if any, weight to allocative efficiency when formulating the antitrust laws, while the prevention of large gains to those who organized monopolistic cartels or inergers is probably a major concern of the public in its commitinent to coinpetition." 57 The Chicago enthusiasts respond that although the framers of the Sherman Act did not speak in terms of "allocative efficiency" as such, their intent was to prevent the economic consequences that such inefficiency causes. ${ }^{58}$ Congress' overriding concern was economic welfare, not social and pohtical issues. ${ }^{59}$

Commentators have posited alternative objectives that antitrust should seek to achieve. ${ }^{60}$ These include the preservation of sinall business and the dispersal of political power by preventing excessive economic concentration. ${ }^{61}$ While the Supreme Court has lately focused on efficiency, the Warren Court placed emphasis on social and pohitical fac-

53. Frank N. Easterbrook, Workable Antitrust Policy, 84 Mich. L. REv. 1696, 1703 (1986).

54. Charles F. Rule \& David L. Meyer, An Antitrust Enforcement Policy to Maximize the Economic Wealth of All Consumers, 33 ANTITRust BulL. 677, 679-80 (1988).

55. Peter W. Rodino, Jr., The Future of Antitrust: Ideology vs. Legislative Intent, 35 ANTITRUST BULL. 575, 598 (1990).

56. John J. Flynn, The Reagan Administration's Antitrust Policy, "Original Intent" and the Legislative History of the Sherman Act, 33 ANTITRUST BULL. 259, 268 (1988) (noting that Congress "had no idea of the technical neoclassical concept of economic efficiency"); Rodino, supra note 55, at 581.

57. Leonard W. Weiss, An Analysis of the Allocation of Antitrust Division Resources, in THE ANTitrust Dilemma 35 (James A. Dalton \& Stanford L. Levin eds., 1974), quoted in David B. Audretsch, Divergent Views in Antitrust Economics, 33 ANTITRUST BuLl. 135, 142 (1988).

58. See Rule \& Meyer, supra note 54, at 688 n.15.

59. Id. at 687 .

60. See Terry Calvani \& Michael L. Sibarium, Antitrust Today: Maturity or Decline, 35 ANTITRUST Bull. 123, 124-25 (1990) (reviewing different possible objectives of antitrust law).

61. Id. at 124; see also United States v. Trans-Missouri Freight Ass'n, 166 U.S. 290, 323-24 (1897) (characterizing one objective of antitrust law as preventing overconcentration of capital); United States v. Aluminum Co. of Am., 148 F.2d 416, 427 (2d Cir. 1945) (noting that preservation of sinall business is a goal of antitrust law). 
tors, rather than efficiency. ${ }^{62}$ The result is that "the Supreme Court has not voiced a consistent statement of the purpose of the antitrust laws." 63

Finally, other commentators have argued that Congress developed "no coherent set of criteria" and that the courts should not look for congressional intent im interpreting the Sherman Act. ${ }^{64}$ Proponents of this position contend that the Sherman Act was motivated inore by specific conditions of the time and less by a pure ideological desire for competition. In the mid to late $1880 \mathrm{~s}$, major trusts were formed in cotton oil, sugar, whiskey, salt, and meat. ${ }^{65}$ One commentator wrote, "The Congress of 1890 had quite a few [fears] growing out of the appearance of cartels, the phight of farmers, railroad rates, so-called destructive competition, the size of eastern banks, and, above all, the activities of the Standard Oil Company."66 These theorists argue that there is no "objective" behind the Sherman Act as current commentators use the word. Congress, according to this view, was merely trying to address immediate probleins, not to establish a dynamic ideology.

While a lack of consensus is evident, it is nonetheless inpossible to discuss the prospect of antitrust reform without first deciding upon the objective(s) behind the antitrust laws. ${ }^{67}$ There must be a standard by which to judge conduct and determine whether a restraint is acceptable under the Sherman Act. Realizing this need, the courts, commentators, and even critics have more or less reached consensus that efficiency is the appropriate objective when analyzing antitrust issues. Even some scholars who do not believe efficiency is the sole goal of the Sherman Act have adopted an efficiency standard for the purposes of legal analysis because it is "the most widely accepted cliaracterization of federal antitrust policy."68 Accordingly, this Comment will use the efficiency-based standard, explaining what it means and why it is the most appropriate standard for antitrust analysis.

62. See Robert H. Lande, The Rise and (Coming) Fall of Efficiency as the Rule of Antitrust, 33 ANTITRUST BULL. 429, 429 (1988).

63. Calvani \& Sibarium, supra note 60 , at 126.

64. See Robin Carey, The Sherman Act: What Did Congress Intend?, 34 ANTITRUst BuLl. 337, 358 (1989). For a fuller discussion of various schools of thought on the original intent behind the Sherman Act, see Flynn, supra note 56.

65. Carey, supra note 64, at 339. One senator referred to trusts in "nails, lead, copper, steel rail, iron nuts and washers, barbed fence wire, slate-pencils, nickel, zinc, jute bags, gutta-percha, castor oil, linseed oil, cottonseed oil, borax and ultramarine." Id. (citing 21 CoNG. REC. 2466 (1890)).

66. Dewey, supra note 40 , at 354 .

67. See BoRk, supra note 49 , at 50 .

68. John S. Wiley Jr., A Capture Theory of Antitrust Federalism, 99 HARV. L. REv. 713, 748 (1986). 


\section{Competition Is a Means to Achieve Efficiency}

\section{The Two Types of Efficiency}

This Comment discusses two types of efficiency: productive efficiency and allocative efficiency. ${ }^{69}$ The purpose of efficiency is to maximize societal resources. Efficiency can be achieved by efficient use of inputs (productive efficiency) and efficient quantity of output (allocative efficiency). This distimction is important because the Supreme Court has recognized the legitimacy of productive, but not allocative, efficiency. Unfortunately, the term "efficiency" is used imprecisely by courts and commentators, without recognition of its dual ineaning. ${ }^{70}$ This Comment, by examining the type of efficiency at issue in individual Supreine Court cases, will illustrate how the two are treated differently under antitrust laws.

Productive efficiency refers to efficiency within a single industry, involving the minimization of unit costs of goods and services within individual firms and the exploitation of economies of scale. When conduct shifts the supply curve out (and therefore makes a greater quantity available at a lower cost), it is productively efficient because a given quantity is supplied at a lower cost. The Court, however, in discussing productive efficiency, is not consistent in its terminology. Although the Court has soinetimes used the phrase productive efficiency, it also has referred to inarketing efficiency, ${ }^{71}$ economies of scale, ${ }^{72}$ and distribution efficiency. ${ }^{73}$ These are simply different terms for and forms of productive efficiency.

Allocative efficiency refers to efficiency of output across industries, involving the question of wliether societal resources should be invested in one industry as opposed to anotler. Whereas productive efficiency seeks to nuanipulate the supply curve, allocative efficiency takes the supply curve as a given. ${ }^{74}$ It does not examine the costs of inputs or how they are used in the manufacturing process. Productive efficiency lias allocative elements in the sense that each business is allocating inputs. However, this is distinct from allocative efficiency whicl, as used in this Comment, deals solely with the quantity produced and consumed. A

69. Economists have delineated several different forms of efficiency. See RoBERT S. PINDYCK \& DANIEL L. Rubinfeld, MiCROECONOMICS 557-89 (1989) (explaining input, output, and exchange efficiencies). Such precision is not necessary for the analysis involved in this Coininent.

70. See Wiley, supra note 68 , at $749 \&$ n.166 (suggesting that the efficiency goal has been adopted by the Supreine Court, though the Court's language varies); cf. Sins \& Lande, supra note 50, at 304 ("To the body politic, 'allocative efficiency' is gibberish . . . .").

71. Continental T.V., Inc. v. GTE Sylvania, Inc., 433 U.S. 36, 55 n.23 (1977).

72. Northwest Wholesale Stationers, Inc. v. Pacific Stationery and Printing Co., 472 U.S. 284, 295 (1985).

73. Monsanto Co. v. Spray-Rite Serv. Corp., 465 U.S. 752, 763-64 (1984); Sylvania, 433 U.S. at 54.

74. Both productive and allocative efficiency take the denand curve as exogenous. 
given level of output is allocatively efficient if the cost of producing the last unit (the niarginal cost, $M C$ ) equals the value of that unit to the last consumer (the marginal benefit, $M B$ ). If one less unit were produced, there would be inefficiency because the marginal consunier values one additional unit more than it would cost society to produce it $(M B>$ $M C$ ). Similarly, if one more unit were produced, there would be inefficiency because it costs society more to produce the additional unit than society values it $(M C>M B)$.

\section{Competition Facilitates Allocative Efficiency, But Its Relationship to Productive Efficiency Is Less Clear}

Productive efficiency and allocative efficiency have different relationships to competition. Productive efficiency may facilitate or even diminish competition, but it is not necessary for competition to occur. Productive efficiency can facilitate competition when sinaller firms.try to gain greater market share. If one producer holds a dominant position in the market, it may be difficult for potential competitors to get a foothold. The most effective mechanism to contest market dominance is price competition. Thus, emerging firms have incentives to be productively efficient - in other words, to decrease production costs and lower prices-in order to compete effectively. However, productive efficiency is not necessary for competition. In an industry with inefficient producers, there can still be perfect competition. For exanuple, $\dot{n} 1$ industries dominated by labor unions, firms may eniploy more labor inputs than they otherwise would. The firms are inefficient in that they are not producing inaximum output at minimum cost. However, the niarket for the final product is perfectly competitive because firms can still charge their marginal cost; the resulting prices are simply higher than if there were productive efficiency. Therefore, perfect competition can exist without productive efficiency. Although productive efficiency may make a single firm inore competitive, this efficiency is not a necessary coinponent of competition as a process. Finally, in some cases productive efficiency can diminish competition. If a firm achieves sufficient econornies of scale, it can supply the entire market at a lower cost per unit than any potential coinpetitors. This advantage results in a natural monopoly if that firm does indeed begin to supply the entire market. A natural monopoly is achieved through productive efficiency and is, by definition, the antithesis of competition. ${ }^{75}$

Conipetition and allocative efficiency, on the other hand, n1aintain a strict means-end relationship. Competition is a means to achieve alloca-

75. Additionally, there is some evidence that competition undermines productive efficiency because only those firms with significant market power have sufficient incentives to invest in innovation. Phillip Areeda \& Louis Kaplow, ANTtTrust ANalysis 36-39 (4th ed. 1988). 
tive efficiency. ${ }^{76}$ The Supreme Court has acknowledged this means-end relationship, noting that competition is a mechanism for "the rational and efficient allocation of resources."77 In Northern Pacific Railway Co. v. United States, ${ }^{78}$ the Court noted that the Sherman Act "rests on the premise that the unrestrained mteraction of competitive forces will yield the best allocation of our economic resources."79 Similarly, one court of appeals observed that "[t]he purpose of antitrust law, at least as articulated im the modern cases, is to protect the competitive process as a means of promoting economic efficiency."80 The Sherman Act's frainers, too, recognized that competition was a means to maximize efficiency. ${ }^{81}$ Economists have concluded that "[i]n sum, the antitrust laws rest upon the assumption that a workably competitive marketplace will achieve a more efficient allocation of resources."

Many circuits have exphicitly recognized that efficiency is the ultimate objective, and competition merely the means to that end. Judge Posner noted that the emphasis of antitrust has shifted "from the protection of competition as a process of rivalry to the protection of competition as a means of promoting economic efficiency."83 Courts have sometimes reasoned that efficiency outweighs possible anticompetitive effects because of this means-end relationship. ${ }^{84}$ After all, it would be irrational to sacrifice the end for the means.

\section{The Supreme Court and Efficiency: Three Different Approaches}

The Court rarely analyzes efficiency as an independent variable. Customarily, efficiency is discussed im the context of competition. The

76. This argument assumes that the other Pareto conditions for maintaining a free market are satisfied. When they are not, competition may not be an appropriate means to achieve allocative efficiency. See infra Part Ir.

77. City of Lafayette v. Louisiana Power \& Light Co., 435 U.S. 389, 408 (1978); see also Jefferson Parish Hosp. Dist. No. 2 v. Hyde, 466 U.S. 2, 12 (1984) (" 'Basic to the faith that a free economy best promotes the public weal is that goods must stand the cold test of competition; that the public, acting through the market's impersonal judgment, shall allocate the Nation's resources and thus direct the course its economic development will take.' ") (emphasis added) (quoting TimesPicayune Publishing Co. v. United States, 345 U.S. 594, 605 (1953)).

78. 356 U.S. 1 (1958).

79. Id. at 4 .

80. Morrison v. Murray Biscuit Co., 797 F.2d 1430, 1437 (7th Cir. 1986).

81. Rule \& Meyer, supra note 54, at 691.

82. Stephen Breyer, Regulation AND Its Reform 158 (1982). The Court, however, precmpted the possibility that this assumption may be incorrect by asserting that "even were that premise open to question, the pohicy unequivocally laid down by the [Sherman] Act is competition." Northern Pac, Ry., 356 U.S. at 4. While acknowledging the importance of competition, the Court has explained that "competition based on efficiency is a positive value that the antitrust laws strive to protect." Connell Constr. Co. v. Plumbers Loeal Umion No. 100, 421 U.S. 616, 623 (1975).

83. Olympia Equip. Leasing Co. v. Western Umon Tel. Co., 797 F.2d 370, 375 (7th Cir. 1986) (emphasis added), cert. denied, 480 U.S. 934 (1987).

84. See, e.g., Rothery Storage \& Van Co. v. Atlas Van Lines, Inc., 792 F.2d 210 (D.C. Cir. 1986) (Wald, J., concurring) (agreeing that a finding of efficiency makes balancing of pro- and anticompetitive effects unnecessary), cert. denied, 479 U.S. 1033 (1987). 
Court has not been consistent, however, in defining the role of efficiency in antitrust law. While not acknowledging the distinction between productive and allocative efficiency, the Court has characterized the relationship between efficiency and coinpetition in three different ways. First, efficiency is irrelevant; coinpetition is the only decision variable. Second, efficiency and coinpetition are synonymous. Third, efficiency outweighs competition. The Court has never exphicitly taken the third position; rather, it has reasoned that efficiency is "procoinpetitive." Yet despite its procompetition rhetoric, this Comment argues, the Court has effectively upheld efficient trade restraints at the expense of coinpetition.

\section{a. Efficiency Is Irrelevant}

The most common interpretation of the relationship between efficiency and coinpetition is that coinpetition is the ultimate currency under the rule of reason; therefore, efficiency is irrelevant. Similarly, per se rules exist because some conduct is presumptively anticoinpetitive, not because such conduct is presuinptively inefficient. To the extent that coinpetition and efficiency come into conflict, efficiency is irrelevant because competition is the sole decision variable. The Court in SoconyVacuum specifically forbade courts from considering efficiency arguments: "Whatever economic justification particular price-fixing agreements may be thought to have, the law does not permit an mquiry into their reasonableness." 85 Even if the Supreine Court did apply the rule of reason to horizontal price-fixing cases, the rule of reason does not perunit a reviewing court to weigh the anticompetitive effects of challenged behavior against potential benefits. The Court refuses to entertain the arguinent that competition may itself, in some cases, be disadvantageous. In National Society of Professional Engineers v. United States, ${ }^{86}$ the Court concluded that the rule of reason "is not to decide whether a policy of favoring competition is im the public interest." 87 There is an irrebuttable presumption that competition is beneficial. The Court noted that "[ $t]$ he statutory policy [behind the Shernnan Act] precludes inquiry into the question whether competition is good or bad. . . . In suin, the Rule of Reason does not support a defense based on the assumption that competition itself is unreasonable." 88 Indeed, the Court in Gordon v. New York Stock Exchange ${ }^{89}$ proclaimed that "the sole aim of antitrust legislation is

85. United States v. Socony-Vacuum Oil Co., 310 U.S. 150, 226 n.59 (1940).

86. 435 U.S. 679 (1978).

87. Id. at 692 .

88. Id. at 695-96. In National Society, the Court reasoned that the Sherman Act reflected a congressional judgment that competition is desirable and that any departure from this stance would have to be made by the legislature. See id. at 689-96. This is an odd rationale, given that most antitrust law is created by the courts, including the rule of reason itself. Furthermore, the Court has accepted diminished competition in some areas. See infra text accompanying notes 113-62.

89. 422 U.S. 659 (1975). 
to protect competition."90 Taken literally, this prevents any argument that competition can be outweigled or that competition can be undesirable.

\section{b. Efficiency Is Competition}

The Supreme Court sometimes views efficiency and competitiveness as synonymous. In sucl situations, the Court mistakenly assumes that all beliavior that is procompetitive is efficient and that nothing can be efficient that is not procompetitive. Indeed, the Court has used tlie concepts of competitiveness and efficiency intercliangeably. ${ }^{91}$ For example, the Court has expressed the rule of reason by asking whether the suspect conduct was "one designed to increase economic efficiency and render markets more, rather than less, coinpetitive." "92 This could be read as reversing the ineans-end relationship to one where efficiency is a ineans to achieve competitiveness.

\section{c. Efficiency Can Outweigh Competition}

Although the Supreme Court lias lield that competition is the overriding objective of antitrust laws and cannot be traded off against competing goals, in some cases the Court lias tolerated decreased competition in order to improve productive efficiency. ${ }^{93}$ This is consistent with the Chicago Scliool's contention that efficiency is the ultimate goal. ${ }^{94}$ Competition is merely a means to, or a proxy for, efficiency. When the Court or legislature can analyze efficiency directly, it is pointless to rely on competition as a proxy.

The Court has einphasized productive efficiency, to the exclusion of competition, in several contexts. This deference to efficiency is illustrated by the Court's treatment of inonopolies under Section Two of the Sherman Act and soine suspect behavior under Section One, including horizontal price-fixing.

The following discussion lays the foundation for three arguments. First, the Court lias admitted tliat competition is not always beneficial. Second, while the Court lias permitted productive efficiency to predominate at the expense of competition, it has refused to give similar consideration to allocative efficiency. The Court lias never explained why productive and allocative efficiency slionld be treated differently. The Court's treatment of productive efficiency is the thin end of the wedge for demanding similar treatınent of allocative efficiency, particu-

90. Id. at 689 .

91. See NCAA v. Board of Regents of the Univ. of Okla., 468 U.S. 85, 114 (1984) (discussing "procompetitive efficiencies").

92. Broadcast Music, Inc. v. CBS, 441 U.S. 1, 20 (1979) (quoting United States v. United States Gypsum Co., 438 U.S. 422, 441 n.16 (1978)).

93. See infra text accompanying notes 100-04.

94. See supra notes $49-52$ and accompanying text. 
larly in cases of horizontal price-fixing. Third, allocative efficiency should be permitted to outweigh coinpetition when the two conflict, because the Court can no longer claim that competition is sacrosanct, nor can it claim that the economic analysis of efficiency defenses is too demanding.

\section{i. Monopolies Under Section Two of the Sherman Act}

Productive efficiency has been found to outweigh competition in some Section Two cases that allow inonopolies. Section Two of the Sherman Act provides that "[e]very person who shall inonopolize, or attempt to inonopolize, or coinbine or conspire with any otler person or persons, to inonopolize any part of the trade or commerce ainong the several States, or with foreign nations, shall be deeined guilty of a misdemeanor."95 As with Section One, ${ }^{96}$ while the prohibition seems comprehensive, the government often grants inonopolies. Sornetimies, the inonopolies are granted to specific imdustries, such as pliones and utihties. ${ }^{97}$ Soinetimes, grants of inonopoly power are in the form of patents and copyright to reward innovation and encourage research and developinent. ${ }^{98}$ Thus, monopolies are sometimes granted to achieve productive efficiency.

Monopoly is the antitlesis of competition, yet the Court has consistently held that the Sherman Act does not punish all inonopolies. The Court in United States v. Grinnell Corp. ${ }^{99}$ concluded that "growtl or development [of a inonopoly] as a consequence of a superior product, business acuinen, or historic accident" is not condemned. ${ }^{100}$ Natural inonopohes and efficient monopolies are not illegal under the Sherman Act. ${ }^{101}$

Section Two cases chip away at the Supreme Court's taboo against questioning the desirability of competition. In uplrolding monopolies under Section Two of the Slierman Act, the Court has allowed other

95. 15 U.S.C. § 2 (Supp. III 1991).

96. For a discussion of Section One, which applies to trade restraints, see infra text accompanying notes $105-10$.

97. See also Pacific Gas \& Elec. Co. v. Public Utils. Comm'n, 475 U.S. 1, 34 (1986) (Rehnquist, J., dissenting) (noting that PG\&E submitted to extensive regulatory authority when it was granted legal monopoly status); Central Hudson Gas \& Elec. Corp. v. Public Serv. Comm'n, 447 U.S. 557, 566 (1980) (recognizing the utility's monopoly over sale of electrieity).

98. See, e.g., Merchant \& Evans, Inc. v. Roosevelt Bldg. Prods. Co., 963 F.2d 628, 639 (3d Cir. 1992); United States v. Studiengesellschaft Kohle, 670 F.2d 1122, 1127 (D.C. Cir. 1981).

99. 384 U.S. 563 (1966).

100. Id. at 570-71 ("The offense of monopoly under $\$ 2$ of the Sherman Act has two elements: (1) the possession of monopoly power in the relevant market and (2) the willful acquisition or maintenance of that power as distinguished from growth or development as a consequence of a superior product, business acumen, or historic accident.") (emphasis added).

101. See Alaska Airlines, Inc. v. United Airlines, Inc., 948 F.2d 536, 548 (9th Cir. 1991) ("The antitrust laws tolerate both efficient monopolies and natural monopolies."), cert. denied, $112 \mathrm{~S}$. Ct. 1663 (1992). 
objectives to outweigh coinpetition. For example, in Aspen Skiing Co. v. Aspen Highlands Skiing Corp. ${ }^{102}$ the Court ruled that monopoly behavior was permissible if done for a "normal business purpose," which in that case was defined in terms of productive efficiency. ${ }^{103}$

In the case of natural monopolies, competition is explicitly curtailed for efficiency. Where a natural monopoly exists, the cost of producing an additional unit is continuously falling. In cases where there are significant economies of scale, greater productive efficiencies are achieved when one manufacturer supplies the whole inarket. The Court upholds natural inonopolies because they are productively efficient. ${ }^{104}$

Iroincally, a permissible monopoly and a perfect cartel have the same economic effect on consumers: they will restrict supply by the same amount and drive up price to the same level. Yet the Court has consistently refused to consider allowing horizontal price-fixing. Of course, a monopoly can exploit economies of scale that cartels cannot. The relevant point here is that the Court lias at times sacrificed competition for efficiency. Monopoly is not inherently, intrinsically bad, and competition is not inherently, intrimsically good.

\section{ii. Restraimts Under Section One of the Sherman Act}

While Section Two of the Sherman Act applies to monopolies, Section One of the Act prohibits those acts which unreasonably restrain trade. ${ }^{105}$ In Section One cases not involving horizontal price-fixing, the Court has upheld restramts that decrcase competition but enhance productive efficiency. For example, vertical restrictions liave been sustained because of distribution efficiencies. ${ }^{106}$ Similarly, Section One of the Slerman Act does not reach coordination between a corporation and its divisions partly because productive efficiencies miglit otlerwise be lost through decentralized management. ${ }^{107}$

Indeed, some restraints are judged under tlie rule of reason because

102. 472 U.S. 585 (1985).

103. Id. at 608 (finding the jury's conclusion that Ski Co.'s conduct was not justified by a normal business purpose to be strongly supported by Ski Co.'s failure to offer any efficiency justification); see also Phillip Areeda, Antitrust Law as Industrial Policy: Should Judges and Juries Make It?, in ANTITRUST, INNOVATION, AND COMPETITIVENESS 29, 38 (Thomas M. Jorde \& David J. Teece eds., 1992) ("[L]ower courts also regularly protect efficiency and innovation against charges of monopohization and attempted monopolization.").

104. See Alaska Airlines, 948 F.2d at 548.

105. 15 U.S.C. $\$ 1$ (Supp. III 1991).

106. See Continental T.V., Inc. v. GTE Sylvania, Inc., 433 U.S. 36, $54-57$ (1977). In discussing vertical restraints, the Court has held that "the legality of arguably anticompetitive conduct should be judged primarily by its 'market impact." " Monsanto Co. v. Spray-Rite Serv. Corp., 465 U.S. 752, 762 (1984) (citing Sylvania, 433 U.S. at 51). The "market impact" in Sylvania involved trading off intrabrand competition against interbrand competition. Sylvania, 433 U.S. at 51-55.

107. See Copperweld Corp. v. Independence Tube Corp., 467 U.S. 752, 771 (1984). Vertical integration may decrease competition because manufacturers no longer bid for imputs in a competitive market; rather, they supply themselves. 
they might increase productive efficiency. In one case, the Supreine Court stated that restraints such as "inergers, joint ventures, and various vertical agreeinents" 1nay increase a firm's efficiency and thus enable it to coinpete inore effectively. ${ }^{108}$ Additionally, the Court has used economies of scale to justify cooperative purchasing agreenents. ${ }^{109}$ Finally, Justices have exphicitly reasoned that productive efficiency can outweigh conpetition in certain trade restraint cases. For example, Justice O'Connor, concurring in the judgment in Jefferson Parish Hospital District No. 2 v. Hyde, ${ }^{110}$ applied the rule of reason to a tying arrangernent and concluded that "tying may inake the provision of packages of goods and services more efficient. A tie-in should be condemned only when its anticompetitive impact outweighs its contribution to efficiency." 111

The Court's charitable treatment of vertical restraints that serve productive efficiency has gradually, though less overtly, extended to horizontal restraints. Officially, in horizontal price-fixing cases, the Court will not entertain efficiency justifieations for anticompetitive conduct. ${ }^{12}$ As the following discussion shows, however, in reality the Court has permitted horizontal price-fixing when defendants show that their arrangements facilitate productive efficiency. In its earhier cases, the Court achieved this result by creatively interpreting what constitutes price-fixing. More recent cases come closer to proclaiming a general rule that productive efficiency may justify horizontal price-fixing.

Chicago Board of Trade (1918)-In the 1918 case Chicago Board of Trade v. United States, ${ }^{113}$ the Court accepted a plan which fixed prices for at least part of the busmess day. In 1906, the Chicago Board of Trade adopted the "Call rule" which prohibited members "from purchasing or offering to purchase, during the period between the close of the Call and the opening of the session on the next business day, any wheat, coru, oats or rye 'to arrive' at a price other than the closing bid at the Call."114 The Call rule prevented sales except at the closing price. Between 2 p.m. and the market's opening at 9:30 a.m. the next morning, deals could only be made at the closing price.

The Court characterized and upheld the Call rule as a restriction on the time of trade as opposed to price-fixing. ${ }^{115}$ This characterization does not seem accurate. First, the Court's own language indicates that

108. Id. at 768 .

109. Northwest Wholesale Stationers, Inc. v. Pacific Stationery and Printing Co., 472 U.S. 284, 295 (1985).

110. 466 U.S. 2 (1984).

111. Id. at 42 (O'Connor, J., concurring in the judgment).

112. See United States v. Socony-Vacuun Oil Co., 310 U.S. 150, 218 (1940).

113. 246 U.S. 231 (1918).

114. Id. at 237.

115. Id. at 239 . 
the Call rule amounted to, at the least, a variation of price-fixing. The Court noted that "after the adoption of the rule, the bids had to be fixed at the day's closing bid on the Call until the opening of the next session." 116 Prior to the Call rule, members were free to change their prices throughout the day in response to market conditions. ${ }^{117}$ Now they were forbidden to negotiate price in their dealings after 2 p.m. Before the rule, prices fluctuated. ${ }^{118}$ Now price could only fluctuate for four and one-half hours per day. ${ }^{119}$ Second, the Call rule could not be accurately characterized as a business hour restriction because "there was no restriction upon the sending out of bids after close of the Call." ${ }^{120}$ Trades could still occur; they simply had to occur at the fixed price.

Under per se rules, the first question should be whether the arrangement constitutes pricc-fixing. Actual effects and justifications are not supposed to be considered. ${ }^{121}$ However, the Court in Chicago Board of Trade analyzed the effects of the Call rule before deciding whether the agreement constituted price-fixing. The Court argued that "the rule had no appreciable effect on general market prices." 122 While discounting possible price effects of the Call rule, the Court laid out several productive efficiency justifications. ${ }^{123}$ The per se rule was thus disregarded to pursue productive efficiency.

Appalachian Coals (1933)-In Appalachian Coals, Inc. v. United States, ${ }^{124}$ the Court sustained an agreement which was, for all intents and purposes, a horizontal price-fixing agreenent. Motivated by productive efficiency arguments, the Court went to great lengths to argue that the agreement did not constitute price-fixing and, therefore, was not subject to the per se rule. ${ }^{125}$

During the Great Depression, coal compamies in the Appalachian territory were competing so fiercely that the price of coal was driven to extreinely low "distress" prices. In response to distress prices for coal, 137 coal companies coalesced and created Appalachian Coals, Inc. ("the Company") to operate as the exclusive selling agency for the coal producers. Through uniform contracts, the defendants authorized the Company "to establish standard classifications, to sell all the coal of all

116. Id. at 237 (emphasis added).

117. Id.

118. See id.

119. See id.

120. Id. at 239.

121. See Northern Pac. Ry. v. United States, 356 U.S. 1, 5 (1958).

122. Id. at 240 .

123. These included regulated market hours, distribution efficiency, and facilitating direct relations between buyers and sellers. Chicago Bd. of Trade, 246 U.S. at 240-41.

124. 288 U.S. 344 (1933), overruled on other grounds by Copperweld Corp. v. Independence Tube Corp., 467 U.S. 752 (1984).

125. See id. at $360-72$. 
its principals at the best prices obtainable and, if all cannot be sold, to apportion orders upon a stated basis."126 Because competitive bidding might drive prices too low, the coal producers colluded. These 137 producers could no longer bid against each other and, therefore, there was no price competition. ${ }^{127}$ This would seem to represent the epitome of price-fixing.

However, the Court declined to apply the per se rule against horizontal price-fixing in this case, reasoning that "[t]he plan cannot be said either to contemplate or to mvolve the fixing of market prices." ${ }^{128}$ This statement is ironic, if not disingenuous. The Court itself noted, when describinig the arrangement, that " $[t]$ he plan contemplates that prices are to be fixed by the officers of the Company at its central office." 129 The Court also noted, and did not refute, the district court's general finding that the plan would "have a tendency to stabilize prices and to raise prices to a higher level than would prevail under conditions of free competition." 130 This result is, by definition, price-fixing. ${ }^{131}$

The Court seemed persuaded by the coal producers' productive efficiency arguments that the price-fixing schenie was impleniented to achieve "better methods of distribution ... [and] economies in marketing." 132 Also, the Court reasoned that the company carried with it no "monopolistic menace" (market power) and that the plan was necessary to restore fair competition in a depressed industry. ${ }^{133}$ These questions are supposedly irrelevant under the per se doctrine. The substance of the Court's discussion is less important than the fact that it took place at all. If the per se rule were applied, the mquiry would have stopped as soon as the Court determined the plan's intent "that prices are to be fixed."134 The per se rule was not applied, im part, because the defendants presented productive efficiency justifications for their price-fixing arrangement. Although not stated explicitly, a productive efficiency exception to the per se doctrine was being carved out. ${ }^{135}$

126. Id. at 358.

127. See id.

128. Id. at 373.

129. Id. at 358 (emphasis added).

130. Id. at 359.

131. See United States v. Socony-Vacuum Oil Co., 310 U.S. 150, 221 (1940).

132. Appalachian Coals, 288 U.S. at 359.

133. Id. at 374 .

134. Id. at 358.

135. In contrast, the Socony-Vacuum Court refused to entertain arguments that price fixing was necessary to stop below-cost, distress prices. The Court distinguished Appalachian Coals on the grounds that there the price setting was determined by an agency rather than the defendants and that the price plan had never been put into actual effect. Socony-Vacuum, 310 U.S. at 214-16. Nevertheless, the Appalachian Coals Court's holding on price plans has not been given any weight following Socony-Vacuum. See, e.g., Virginia Excelsior Mills, Inc. v. FTC, 256 F.2d 538, 541 (4th Cir. 1958) ("[Appalachion Coals] has not survived the strong and consistent course of subsequent 
Broadcast Music (1979)-In 1979, the Court's decision in Broadcast Music, Inc. v. $C B S^{136}$ was a turning point in the application of the per se rule to horizontal price-fixing. The defendants, Broadcast Music, Inc. ("BMI") and American Society of Coinposers, Autliors and Publisliers ("ASCAP"), controlled the license rights to nearly every copyrighted coinposition in the United States. ${ }^{137}$ In order to broadcast any coinposition in BMI or ASCAP's repertory, television and radio stations had to purchase a blanket license which for a single fee granted the purchaser access to all compositions. For example, ASCAP required a consumer to purchase a blanket license for all ASCAP copyrighted music even if the consumer only wanted to use a limited number of copyriglited materials. ${ }^{138}$ There was no price competition among individual composers to market their product to television or radio stations. Again, this is the essence of price-fixing.

The Court ruled that the blanket license scheine did not constitute price-fixing and therefore per se illegality was inappropriate. ${ }^{139}$ The majority brushed aside the fact that blanket licenses actually fixed prices for inusical conıpositions with the argument that "[t]he record disclosed price fixing only in a 'hiteral sense." "140 The Court reasoned that "[w]lhen two partners set the price of their goods or services they are literally 'price fixing,' but they are not per se in violation of the Sherman Act." ${ }^{141}$ This reasoning is a red herring because arrangenients between partners wonld never be illegal under the Sherman Act. The Act limits price-fixing arrangeınents between separate entities; ${ }^{142}$ business partners do not constitute separate entities. In deciding that blanket licenses are not price-fixing, the Court entirely disregarded its own definition of price-fixing established in Socony-Vacuum and applied in subsequent cases. ${ }^{143}$

In applying the rule of reason, the Court einpliasized three productive efficiency justifications for the blanket license. First, the inarket for conipositions niay not exist witlıout blanket licenses. Second, individual contracts wonld be too difficult to negotiate. Third, blanket licenses decrease transactions costs. ${ }^{144}$ These are all productive efficiency arguments because they affect the sliape (or existence) of the supply curve.

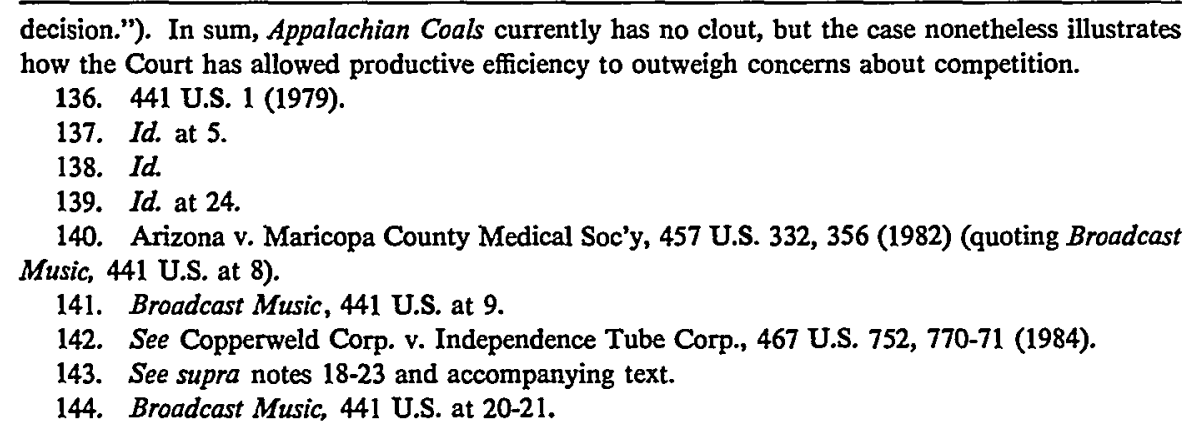


The Court never said that blanket licenses were not price-fixing because prices were not actually fixed or affected. Ratlier, in effect, the Court said that there was no price-fixing because blanket licenses are net beneficial. ${ }^{145}$ The majority noted that " 'price fixing' is a shorthand way of describing certain categories of business behavior to which the per se rule has been leld applicable."146 The Court's reasoning is tautological. If conduct is price-fixing, courts will not look at efficiency. However, if something is efficient (read: procompetitive), it is not price-fixing. In other words, the Court concluded that price-fixing can never be efficient because, if it is efficient, then it is not price-fixing. Altliough convoluted, the reasoning of the Court basically allows productive efficiency to outweiglı competition.

If the Court had found that the blanket licensing agreennent represented a case of horizontal price-fixing, then presumably it would never have reached the question of integrative efficiencies or any otler justifications. Applying the per se rule, the licensing arrangeinent would have been immediately condemned, even if there was no anticompetitive effect. Per se rules mandate that as a matter of law, horizontal price-fixing agreements constrain coinpetition and, therefore, are illegal. The purpose of the per se doctrine is to prevent inquiry into whether any individual agreement has an anti- or procoinpetitive effect.

The Court in Broadcast Music wanted to uphold the blanket license. It had two options. First, it could have ruled that this was not a pricefixing agreement and subjected it to the rule of reason, liolding that blanket licenses are a reasonable restraint. Alternatively, the Court could have ruled that blanket hicenses do constitute price-fixing but that because of productive efficiency justifications, the rule of reason would be applied. The Court chose the first option, defining the problem away. In declining to articulate a rule which would account for efficiency concerus, the Court in essence skirted the issue so as to avoid inconsistent application of the per se rule.

In sum, the effect of Broadcast Music is two-fold. First, the per se rule against liorizontal price-fixing has lost unuch of its bite. The sole issue before the Court was whether to apply the per se rule or the rule of reason. The majority basically concluded that the restraint was reasonable and then decided which standard to apply. The Court did not acknowledge that in reality it was creating an exception to the per se rule; instead, it recharacterized the challenged blanket license in order to uphold it and yet maintain the appearance of consistency. Second, the Court acknowledged that competition is not the sole objective of the Sherinan Act. Rather, there are times when competition inust give way

145. See id. at 21-22.

146. Id. at 9. 
to productive efficiency concerns. Both of these conclusions are supported by subsequent cases.

Post Broadcast Music-In NCAA v. Board of Regents of the University of Oklahoma, ${ }^{147}$ the NCAA had implemented a plan with its member colleges limiting the total amount of televised intercollegiate football and the number of games that any one team could televise. No NCAA member was permitted to sell television rights except in accordance with the basic plan. ${ }^{148}$ The district court and court of appeals concluded that this was a classic case of price-fixing, because "NCAA meinbers have sought and achieved a price for their product which is, in most instances, artificially high."149 Further, the NCAA plan "preclude[d] any price negotiation between broadcasters and institutions, thereby constituting horizontal price fixing." 150

Astonishingly, while claiming to "accord great weight to a finding of fact which has been made by a district court and approved by a court of appeals," 151 the Court removed the case from the per se category because it involved "an industry in which horizontal restramts on coinpetition are essential if the product is to be available at all."152 To determine whether the conduct was price-fixing, the Court did not ask whether the plan fixed prices but rather whether the plan was necessary. This approach is inconsistent with the fundamental tenet of the per se rule that horizontal price-fixing is "presumed unreasonable without inquiry into the particular inarket context in which it is found."153

The majority reasoned that the rule of reason should be applied because some cooperation was necessary for "rules affecting such matters as the size of the field, the number of players on a team, and the extent to which physical violence is to be encouraged or proscribed."154 None of these rules were at issue, however; no one was even considering eliminating the NCAA. The complaint was limited solely to decreased quantity of product (televised collegiate sports) and the fixing of prices charged to television networks.

The Court conceded that the NCAA plan was a "naked restraint on price and output"155 and yet went to great lengths to avoid per se treatment. When the Court did apply the rule of reason, it declared the NCAA plan "unreasonable" because "[t]he NCAA's efficiency justifica-

147. 468 U.S. 85 (1984).

148. Id. at 94 .

149. Id. at 96 (quoting Board of Regents of the Univ. of Okla. v. NCAA, 546 F. Supp. 1276, 1301 (W.D. Okla. 1982), aff'd, 707 F.2d 1147 (10th Cir. 1983), aff'd, 468 U.S. 85 (1984)).

150. NCAA, 468 U.S. at $99-100$.

151. Id. at $98 \mathrm{n} .15$.

152. Id. at 101 .

153. Id. at 100 .

154. Id. at 101 .

155. Id. at 110 . 
tion is not supported by the record."156

The important point for our purposes is that the Court in NCAA took a price-fixing scheme out of the per se category because of the potential for productive efficiency. The Court applied the rule of reason but still held the restraint unreasonable. ${ }^{157}$ In prior cases, the Court rejected arguments that price-fixing agreements were reasonable because they decreased the transaction costs of negotiating individual sales. ${ }^{158}$ Regardless of the result in any individual suit, the general siguificance here is the Court's clear willingness to analyze productive efficiency arguinents in horizontal price-fixing cases.

In FTC v. Indiana Federation of Dentists, ${ }^{159}$ the defendants were charged with price-fixing. Citing Broadcast Mrusic, Chicago Board of Trade, and NCAA, the Court applied the rule of reason and specifically held that productive efficiency can justify otherwise anticompetitive conduct:

Absent some countervailing procoinpetitive virtue-such as, for example, the creation of efficiencies in the operation of a market or the provision of goods and services-such an agreement limiting consumer choice by impeding the 'ordinary give and take of the market place' cannot be sustained under the Rule of Reason. ${ }^{160}$

Thus, the Court assumed that productive efficiency is necessarily procoinpetitive. This assumption is false. ${ }^{161}$ The efficiencies discussed in Broadcast Music created an econony of scale that, while cost-mininizing, insured that the entire market was supplied by only two suppliers. Such a market is the antithesis of competition. Even in the absence of econonnies of scale and natural monopolies, productive efficiency can be an effective ineans to eliminate competition. Still, the Court will analyze efficiency justifications for horizontal price-fixing arrangements. When productive efficiency is found, supply restrictions and increased prices are sustained.

In sum, the Supreine Court has not applied the per se rule strictly and, despite its rlietoric to the contrary, has not uniformly applied the

156. Id. at 115 .

157. Id. at $117-20$.

158. See Arizona v. Maricopa County Medical Soc'y, 457 U.S. 332, 353-54 (1982); Catalano, Inc. v. Target Sales, Inc., 446 U.S. 643, 649 (1980). On the other hand, there is language indicating that the Court accepted the justification of decreased transaction costs in Broadcast Music, Inc. v. CBS, 441 U.S. 1, 21-22 (1979).

159. 476 U.S. 447 (1986).

160. Id. at 459 (citations omitted).

161. In part, this false assumption supports the argument that the Court considers competitiveness and efficiency to be similar, if not synonymous. But the Court's language in Indiana Federation of Dentists connotes a balancing that its other opinions do not. In the process of mischaracterizing the means-end relationship between efficiency and competitiveness, the Court exphicitly admitted that productive efficiency can outweigh other anticompetitive tendencies. 
rule that competition outweighs efficiency and other values. The net effect of these decisions is that the per se rule against horizontal pricefixing is not intact. ${ }^{162}$ The Supreine Court has carved out an exception whereby the rule of reason is applied in horizontal price-fixing cases when the defendants argue productive efficiency justifications for their conduct. On the other hand, the Court has still not sustained arguments that allocative efficiency justifies diminished competition. Part II of this Comment argues that allocative efficiency should be a defense in horizontal price-fixing cases.

\section{II}

\section{The Theory OF THE SeCOND Best}

Current judicial decisionmaking im antitrust is based on a series of presumptions. Competition is presnmed, as a matter of law, to be beneficial, and certain restraints are presnmed to be anticoinpetitive. Both presumptions are theoretically irrebuttable. This Comment does not advocate elimination of these presnmptions. Rather, it argues that both presumptions should be rebuttable. Courts can still presnme competition is beneficial and that some conduct has anticoinpetitive effects; however, defendants should be afforded the opportunity to argue that a particular restraint is efficient and should be upheld. This Comment does not exphicitly challenge the irrebuttable presnmption that price-fixing diminishes competition; ${ }^{163}$ rather, it questions the presuniption that competition is necessarily good.

\section{A. The Potential Efficiency of Unregulated Multiple Market Failures}

In their seminal work developing a general theory of the second best, ${ }^{164}$ Professors Lipsey and Lancaster proved mathematically that if all the conditions necessary for Pareto optimality ${ }^{165}$ could not be satisfied, it may be inefficient to satisfy the remainmg conditions. ${ }^{166}$ Lipsey and Lancaster explain that "if there is introduced imto a general equilibrium system a constraint which prevents the attainment of one of the

162. See Calvani \& Sibarium, supra note 60 , at 148-49 (arguing that after Broadcast Music and NCAA the per se/rule of reason distinction is outmoded); Fred S. McChesney, Law's Honour Lost: The Plight of Antitrust, 31 ANTITRUst BuLL. 359, 368-69 (1986) (arguing that Broadcast Music and $N C A A$ are eases where the Court applied the rule of reason to horizontal price-fixing); Sins \& Lande, supra note 50, at 305 ("Recent years have seen the blurring of the per se and rule-of-reason approaches. Only hard-core price-fixing really remains per se illegal.").

163. Some commentators have argued that horizontal price-fixing can, in some cases, facilitate competition. See Richard Schmalensee, Agreements Between Competitors, in ANTITRUST, INNOVATION, AND COMPETITIVENESS, supra note 103, at 98, 98-104.

164. R.G. Lipsey \& Kelvin Laneaster, The General Theory of Second Best, 24 REv. EcoN. STUD. 11 (1956-57).

165. Pareto optimality exists when no individual can be made better off without another individual being made worse off.

166. Lipsey \& Lancaster, supra note 164. 
Paretian conditions, the other Pareto conditions, although still attainable, are, in general, no longer desirable."167 In its simplest form, the theory of the second best suggests that if there are two market failures occurring in a market and the government cannot solve both of thein, it may be more efficient to leave the market unregulated despite the failures. ${ }^{168}$ Government inaction may result in efficiency because market failures can balance each other. For example, some market failures inay cause overconsumption and others underconsumption. Either one alone would create inefficiency but taken together the net effect may be a wash. In other words, two wrongs can make a right-or rather, one wrong would be even worse.

The general theory of the second best can be illustrated in two ways, through production possibility curves ${ }^{169}$ and through standard supply and demand curves. The allocative efficiency that is relevant to horizontal price-fixing is deinonstrated by the latter. The basic free market model predicts that an unregulated market will lead to the efficient price and quantity equilibrium. An efficient equilibrium exists where the supply curve intersects the demand curve and where marginal cost equals marginal benefit. Market failures can prevent the market from achieving this equilibrium. Some market failnres cause underconsuinption, as when monopolists restrict quantity in order to drive prices up. Some market failures cause overconsuinption; examples include negative externalities, predatory pricing, and the tragedy of the commons. ${ }^{170}$

If two market failures exist simultaneously-one causing underconsumption and one causing overconsumption-the theory of the second best holds that the failures can balance each other and create a more efficient equilibrium than if antitrust enforcement eliminated only one market failure. It would be serendipitous, if not miraculous, for two fail-

167. Id. at 11 .

168. In antitrust analysis, the theory of the second best is usually used in the context of efficiency across markets. For example, is it efficient to achieve the Pareto optimal conditions in one market if a market for complements is in disequilibrium? See F.M. SCHERER, INDUSTR1AL Market Structure AND Economic Performance 24-29 (2d ed. 1980). As used in this Comment, "second best" refers to any situation whereby achieving a given Pareto optimal condition diminishes efficiency because the remaining Pareto optimal conditions are not satisfied. This can occur within a market or across markets.

169. Traditionally, the Pareto optimal solution lies along the production possibilities frontier, where the outermost utility curve is tangent to the production possibility frontier. However, if there were a constraint which made the tangency point unattainable, the efficient equilibrium is no longer on the production possibilities frontier. For a fuller, diagrammatic explanation, see WALTER Nicholson, Microeconomic ThEORY 663-65 (3d ed. 1985).

170. The "tragedy of the commons" is a metaphor used to describe those situations where individual self-interest leads to societal overconsumption. The metaphor is commonly illustrated by a common plot of grazing land, where "if no one is authorized to set limits to preserve open pasture land as a whole, allowing sheep to graze on that land may lead to serious overgrazing, as each herdsman thinks only of his own advantage." Natural Resources Defense Council v. Costle, 568 F.2d 1369, 1378 n.19 (D.C. Cir. 1977) (summarizing Garrett Hardin, The Tragedy of the Commons, 162 SCIENCE 1243 (1968)). 
ures to balance perfectly and achieve the first best solution. However, even if this balancing does not achieve the most efficient equilibrium, it is still a better solution than the elimination of only one market failure, which would only serve to shift the equilibrium further away froin the efficient point. Thus, the theory of the second best simply suggests that it might be better to do nothing and accept the imperfect balance, or second best solution, because eliminating the trade restraint would create even more inefficiency.

\section{B. Collusion Is a Market Failure}

The free inarket inodel predicts that unrestrained coinpetition achieves the efficient equilibrium. ${ }^{171}$ This model, however, is based on a series of assumptions. For exainple, the model assumes competition ainong suppliers. ${ }^{172}$ The function of antitrust laws is to correct any market failure that may restrict coinpetition.

As the antithesis of competition, collusion represents a market failure. Collusion can take inany forms. ${ }^{173}$ The most extreine brand of collusion is horizontal price-fixing, whereby producers constrict supply and raise prices. The effect of lorizontal price-fixing is, ceteris paribus, underproduction, one form of allocative inefficiency. Underproduction creates deadweight loss. Thus, trades do not occur despite the fact tliat society values the additional units more tlian it would cost manufacturers to produce tliem.

\section{The Presence of Negative Externalities Is a Market Failure}

The free market model also assumes that the price of a product accurately reflects its cost. When price does not reflect cost and is artificially depressed, demand for the product increases and causes overconsumption. Negative externalities have this effect and are therefore a market failure.

An externality exists when the shelf price of a product does not reflect the total cost to society of production and consumption. An externality is negative when these costs are greater than the price the consuiner pays. The consumer responds to an artificially low price

171. See supra Section I.C. 1 for a discussion of productive and allocative efficiency.

172. The free market model also assumes perfect information, no barriers to entry or exit, and homogeneous products.

173. These include exchanging price information, product standardization, and basepoimt pricing. Basepoint pricing is the policy of charging transportation costs assuming a given base point, regardless of the actual shipping point. See FTC v. Cement Inst., 333 U.S. 683, 714 (1948) (involving basepoint pricing in the cement industry in the 1930s); Triangle Conduit \& Cable Co. v. FTC, 168 F.2d 175, 177 (7th Cir. 1948) (imvolving basepoint pricing in the electric cable industry in the early 1900s). For some of the anticompetitive effects of product standardization, see Allied Tube \& Conduit Corp. v. Indian Head, Inc., 486 U.S. 492, 500 n.5 (1988). 
because she does not have to pay the full cost of consumption. ${ }^{174}$

Overconsumption is undesirable because, although artificially low prices on one product may benefit the consumers of that product, consumers as a whole are worse off. By definition, consumption of a product in excess of the efficient equilibrium (that is, where supply meets demand) costs inore per umit than the individual consumer actually values the product. Moreover, resources spent producing goods with negative externalities would be better spent in other sectors (where marginal cost equals marginal benefit). ${ }^{175}$

The overconsumption that results from negative externalities causes deadweight loss. One type of deadweight loss is the unrealized trades that should have occurred because consumers valued the inarginal product more than the cost of producing it. However, deadweight loss also exists when trades occur that should not have. ${ }^{176}$ That is because distortions in one market diminish the ability of competition to achieve efficient results in other markets. The result is allocative inefficiencyresources that should be used in one market are used in another. ${ }^{177}$ Applying the theory of the second best, the distorting effect of overconsumption could be made worse if, in cases of horizontal price-fixing, antitrust laws are used to decrease prices achieved through collusion.

However, the Court does not seein to recognize that overconsuinption is undesirable. First, by applying per se rules against conduct "that would always or almost always tend to restrict competition and decrease output," 178 the Court assumes decreased output is necessarily bad. The principles of allocative efficiency prove, however, that this is not necessarily true. Instead, the efficient equilibrium depends on the particular product and the current level of consuinption. Both the supply and deinand curves should be determined exogenously, independent of the collusive conduct. Once they are determined there is an objectively efficient equilibriuun. Any output greater than this equilibriuin is inefficient and should be discouraged.

Second, by endorsing the principle that "equal competition will inaximize consumer demand for the product,"179 the Court unakes two assumptions: it assumes that consumption is an imtrinsic good and that government should maximize consumer demand. Both assumptions are

174. See infra Section III.A.1.

175. For example, if the price of tobacco is depressed, demand for tobacco increases. Quantity consumed would increase as the demand curve shifts out along the supply curve. Supply would mcrease (although the supply curve would not shift). Agricultural land that could be more efficiently used to produce alternative crops, considering the negative externalities, would be shifted into tobacco production.

176. Given linear supply and demand curves, the oversupply of quantity $X$ has the same deadweight loss as an undersupply of quantity $X$.

177. See Wiley, supra note 68 , at 752 .

178. Business Elecs. Corp. v. Sharp Elecs. Corp., 485 U.S. 717, 723 (1988) (citations omitted).

179. NCAA v. Board of Regents of the Univ. of Okla., 468 U.S. 85, 120 (1984). 
incorrect. Increased consumption is inefficient once a market has reached the competitive equilibrium. Furthermore, the maintenance of low prices to maximize consumer demand is not the ultimate goal of antitrust; if it were, the courts and Congress would simply establish price ceilings. Indeed, the Court has held that agreements ainong competitors to depress prices are per se illegal. ${ }^{180}$

\section{Collusion Sometimes Produces a More Efficient Outcome}

Despite judicial rhetoric to the contrary, competition can be ineffcient. "An established and abundant literature has elaborated the conditions under which competition enforced by ordinary Sherman Act rules produces inefficiency."181 Competition leads to the efficient outcome ouly when the assumptions underlying the free inarket inodel are satisfied. One such assumption of the free market model is that there are no negative externalities. Yet the judiciary does not seem to recognize the possibility of externalities in its decisions. Price-fixing is condemned because it will "invariably . . . raise prices above cost." 182 No effort is inade to distinguisl between total private and social costs. The Court emphasizes the actual conduct imvolved, ignoring both second order effects and the underlying assumptions of the free market model. ${ }^{183}$

The competition-based economic theory applied by the courts naively assumes that there are no market failures; when market failures are present, lowever, competition will not achieve the efficient equilibrium that maximizes consumer welfare. ${ }^{184}$ Currently, antitrust serves to protect competition as a process "rather than rephicate the results of coinpetition or correct for the defects of competitive markets." 185 If the goal of antitrust is to maximize efficiency in markets as they exist in reality, blind obedience to competition is simply bad economics. Current antitrust doctrine, therefore, overemphasizes the means and loses siglit of the true objective.

The traditional economic response to negative externalities is to "internalize" them. ${ }^{186}$ Indeed, much government policy is designed to internalize externalities. Taxes, regulations, and tort liability are all mechanisnis to "decrease consuniption" of costly behavior and products.

180. United States v. Socony-Vacuum Oil Co., 310 U.S. 150, 223 (1940).

181. Wiley, supra note 68 , at 751-52.

182. Rule \& Meyer, supra note 54, at 701.

183. McChesney, supra note 162 , at 367 .

184. John E. Lopatka, State Action and Municipal Antitrust Immunity: An Economic Approach, 53 FORDHAM L. REV. 23, 56 (1984).

185. BREYER, supra note 82, at 156-57.

186. Internalizing an externality means devising a mechanism that makes shelf price reflect true societal cost. For negative externalities, shelf price should be increased; for positive externalities, decreased. In either ease, internalizing an externality requires determining the efficient equilibrium and adjusting the price. 
The law is replete with examples of creative ways to internalize potential externalities. For example, product liability forces a coinpany to evaluate and minimize downstream costs that it could otlierwise ignore. Cliemical companies liave toxic tort liability as a new incentive to decrease or eliminate emission of pollutants. Finally, manufacturers are compelled to test products to insure thia they are safe before sale, and to recall potentially lrazardous products already sold.

Price collusion is one meclianism for internalizing a negative externality. The beauty of this mechanism is that it utilizes the invisible hand, whereby private individuals, operatimg in their own self interest, will interact and achieve the efficient equilibrium. The invisible hand compensates for the fact that

the competitive market may fail when negative externalities exist. Allocative efficiency would require thiat output be reduced, but a monopolist, attempting solely to maximize his profit, would also reduce output to the point at which marginal revenue equaled his marginal, private cost. The reduced output produced by the monopolist may, by cliance, equal the efficient output, and therefore, his action would increase efficiency. He intended, however, merely to maximize his profit, not to increase efficiency. ${ }^{187}$

By increasing depressed, inefficient shelf prices, liorizontal price fixing can increase efficiency in markets with high negative externalities.

Because collusion can increase efficiency in some markets, courts should allow the market failure defense. Defendants would tlien be able to argue that their anticompetitive behavior increased allocative efficiency. Second best tlieory sliows thiat loorizontal price-fixing can be efficient in some cases. It is incorrect to equate competition witl efficiency. Courts slould not look at competition per se, but at competitive equilibria. The competitive equilibrium is the point at which price and quantity would stabilize in a free market operating without inarket failures. By permitting the market failure defense and applying the rule of reason, courts could incorporate the effect of collusion on the competitive equilibrium.

187. Lopatka, supra note 184 , at 58 n.255. Some may attack the invisible hand because, as Lopatka suggests, it operates "by chance." Unlike government decisionmakers, private colluders do not have an incentive to fix prices to match externalities. They intend to maximize their own profit, not society's overall efficiency. See Einer R. Elhauge, The Scope of Antitrust Process, 104 HARV. L. REV. 667, 701-03 (1991) (arguing that only financially disinterested governmental actors should bc allowed to correct market failures). Their profit-maximizing price may be less or more than the socially efficient price. However, if there were a market failure defense, colluding firms would have an incentive to raise prices to efficient levels, and no higher. 


\section{E. Current Doctrine Precludes a Market Failure Defense}

Unfortunately, while giving some weight to productive efficiency, the Court still focuses on the means and not the end. ${ }^{188}$ Although the purpose of competition is to achieve allocative efficiency, the Court rarely discusses allocative efficiency as a decision variable. The Court has only acknowledged the concept of allocative efficiency to the extent that monopoly is condemned because it causes underconsumption. Even when allocative efficiency is acknowledged, more often than not the Court discounts allocative efficiency as expendable in order to achieve the administrative efficiency of per se rules. ${ }^{189}$ The Court apparently fails to recognize that resource misallocation is not limited to the market at issue in a given lawsuit. ${ }^{190}$ Allocative inefficiency in one market causes inefficiencies in other markets; namely, the markets for substitutes and complements.

Similarly, the executive branch does not look into efficiency effects in price-fixing cases. James F. Rill, the head of the Antitrust Division of the Department of Justice, noted that "[g]ain or loss is not a necessary element of proof for per se antitrust crimes; harm is presumed given the nature of the violation. Thus, the Department traditionally has not investigated gain or loss or made factual damage presentations in its criminal cases."191 Rill falsely assumes that price-fixing has "no economic justification and serve[s] only to raise prices paid by consumers." 192

The Court has precluded a market failure defense in private antitrust suits im four different but related ways. First, as it stated in National Society of Professional Engineers, ${ }^{193}$ the Court has exphicitly refused to analyze market failures in cases where the defendants are private actors. ${ }^{194}$ The Court has reasoned that Congress could make market failure a factor if it desired. ${ }^{195}$ This reasoming is disingenuous, given that most antitrust law is judicially created. Second, no justifications are

188. Even when it is basing a decision on efficiency grounds, e.g., Broadcast Music, Inc., v. CBS, 441 U.S. 1, 22 (1979), the Court uses the language of competition to justify the result. Id. at 14.

189. Sometimes the Court appears more concerned with the efficiency of the court system than the efficiency of the marketplace. See FTC v. Superior Court Trial Lawyers Ass'n, 493 U.S. 411, 430 (1990) ("The administrative efficiency interests in antitrust regulation are unusually compelling. The per se rules avoid 'the necessity for an incredibly complicated and prolonged economic investigation into the entire history of the industry involved ...." ") (citations omitted).

190. The Court does not look across different sectors of the economy in analyzing antitrust issues.

191. To Amend the Sherman Act \& Clayton Acts: Hearing on S. 994, S. 995, and S. 996 Before the Senate Comm. on the Judiciary, 101st Cong., 1st Sess. 11, 24 (1989) (statement of James F. Rill, Asst. Att'y Gen., Dept. of Justice).

192. Id. at 19.

193. National Soc'y of Professional Eng'rs v. Umited States, 435 U.S. 679 (1978).

194. Id. at 695 .

195. See Wiley, supra note 68, at 753 n.182 ("Professional Engineers relied upon Congress's ability to provide an antitrust exemption for situations in which competition is inappropriate."). 
permitted in per se cases. Officially, the Court will not even examine economic justifications in horizontal price-fixing cases. ${ }^{196}$

Third, even in the absence of per se rules, the Court forbids the argument that coinpetition is sometimes undesirable. A market failure defense is based on the fact that competition is not always beneficial. In cases where productive efficiency was accepted as a justification, the Court misconstrued efficiency as synonymous with competition or as procoinpetitive. ${ }^{197}$ Unlike productive efficiency arguments, an allocative efficiency analysis cannot hide the ball and claim that allocative efficiency facilitates the competitive process. It does not; it achieves the competitive result of a free market, not the competitive process. As long as courts refuse to entertain economic arguments against the inherent desirability of competition, defendants cannot argue a narket failure defense. The Court's refusal to admit that competition is not necessarily desirable is ironic, given that the Court has acknowledged that competition merely serves, not masters, efficiency. ${ }^{198}$ The Court inust do inore than merely acknowledge the means-ends relationship between competition and allocative efficiency. It must incorporate this relationship into antitrust doctrine.

Finally, the Court prohibits analysis into the reasonableness of specific prices. A primary principle behind the per se illegality of pricefixing is that the Court will not entertain arguments that a given price is "reasonable." 199 In contrast, allocative efficiency arguments and the theory of the second best are results-oriented. They require courts to examine a price and determine whether that price reflects equilibrium or near-equilibrium inarket conditions. If it is the equilibrium price, it should not be condemned. Without the ability to argue that their prices are reasonable (read: efficient), defendants cannot present a market failure defense. The courts' reluctance to abandon per se rules when they are imconsistent with current economic theory nuay threaten the legiti-

196. United States v. Socony-Vacuum Oil Co., 310 U.S. 150, 228 (1940) ("[P]rice-fixing conubinations which lack Congressional sanction are illegal per se; they are not evaluated in terms of their purpose, ain or effect in the elinination of so-called competitive evils.").

197. See supra Section I.C.3.b.

198. See supra Section I.C.3.c.

199. Atlantic Richfield Co. v. USA Petroleun Co., 495 U.S. 328, 353 (1990) (Stevens, J., dissenting) ("If any proposition is firmly settled in the law of antitrust, it is the rule that the reasonableness of the particular price agreed upon by defendants does not constitute a defense to a price-fixing charge."); United States v. Trenton Potteries Co., 273 U.S. 392, 398 (1927) ("[I]t has ... often been decided and always assumed that uniform price-fixing . . . is prohibited by the Sherman Law, despite the reasonableness of the particular prices agreed upon."). Nevertheless, the judiciary does determine whether prices are reasonable in some contexts, such as in cases involving utility rates. See Federal Power Conım'n v. Hope Natural Gas Co., 320 U.S. 591, 603 (1944) (a "reasonable" rate allows a firm to recover its costs and a reasonable profit); see also 16 U.S.C. $\S \S 824 \mathrm{~d}(a), 824 \mathrm{e}(\mathrm{a})$ (1988) (electric utility rates nust be "just and reasonable"). There is no analytic rationale for not applying the same process in price-fixing cases. 
macy of antitrust. ${ }^{200}$

\section{III}

\section{Application of the Theory of The Second Best}

Although a market failure defense might apply to any market failure that causes overconsumption, this Comment is limited to horizontal price-fixing arrangements for products with negative externalities. Of course, not all horizontal price-fixing arrangements imvolving products with negative externalities should be upheld. Otherwise the exception would swallow the rule, as most goods have some nominal downstream costs im terms of waste disposal, effects on health, or production pollution. To warrant a successful market failure defense, a product must possess four characteristics: (1) it must have negative externalities, (2) it must be undertaxed, (3) it must have elastic demand, and (4) it must have feasible alternatives.

In order to illustrate these requisite characteristics, consider the following three products: tobacco, gasoline, and infant formula. These products all have been the subject of price-fixing suits by the government. The products do not satisfy all of the criteria of the market failure defense, nor are they presented as examples of products that should receive second best protection. They instead help illustrate the essential elements of the defense through discussion of whether each characteristic is, or is not, satisfied by these products.

\section{A. Product Characteristics}

\section{Negative Externality}

The definition and effect of negative externalities have already been discussed. ${ }^{201}$ Three different types of negative externalities are relevant to this Comment's discussion of the market failure defense: non-mternalized costs to the enviroument, to nonconsumers, and to the ultimate consumer. The three types of negative externalities are illustrated, respectively, by gasoline, tobacco, and infant formula.

Non-internalized costs to the enviroument are the traditional, textbook type of externality. When the environment is damaged, society as a whole must eventually pay, in the form either of clean-up costs or of degraded environmental quality. Gasoline has well-known negative environmental costs, including general air pollution, global warming (the greenhouse effect), and drilling damage. If there were no taxes, neither producers nor consumers of gasoline would pay for these environmental effects of gas consumption. In addition to the externalities caused when

200. For a fiery critique of the courts and per se rules, see McChesney, supra note 162, at 36667.

201. See supra Section II.C. 
gasoline is used as intended, externalities result froin accidents-one example is the pollution caused by oil spills. Because the punn price does not include all of the environmental impacts of gasoline consumption, the social costs are greater than the private costs; by definition, there is a negative externality. Consumers do not have to pay for these costs and so they overconsume.

The second type of negative externality involves products which impose costs on nonconsnmers of the item. Tobacco is such a product. The externalities of tobacco consumption include the premature death and suffering of passive smokers; increased inedical costs, sick leave, disability, and group life insurance costs; losses caused by cigarette-related fires; and foregone income tax due to lost earnings. ${ }^{202}$ Smokers do not have to pay for and do not consider these costs since they are not reflected in the price of tobaceo products. Once agam, the costs to society exceed the cost to the consumer, creating a negative externality.

A third and less commonly considered type of negative externality involves products whose non-internalized costs are borne by the ultimate consuiner. Even when the consumer inust pay the downstream costs of a product, the consuiner may undervalue the risks and costs associated with consumption of the product. ${ }^{203}$ This acts like an externality because the consuiner does not perceive the total cost and therefore overconsumes. Most externality analysis assumes that the consumer correctly interprets the shelf price but that that price is too low because the consumer does not have to pay downstream costs. If consuiners incorrectly perceive shelf price, a higher price may be necessary to insure that an efficient equilibrium is achieved. Infant formula is an example of a product with hidden costs. The hidden costs of infant formula include health hazards due to tainted formula ${ }^{204}$ and foregone health benefits associated with breast-feeding. ${ }^{205}$ Because these costs are not readily per-

202. Willard G. Manning et al., The Taxes of Sin, 261 JAMA. 1604, 1605 (1989).

203. See id. at $1608-09$ (noting regret expressed by most smokers and widespread ignorance of risks).

204. See, e.g., Karen Klinger, Wrong Amounts of Vitamin D Added to Most Milk, UPI, Apr. 29, 1992, available in LEXIS, Nexis Library, Wires File (reporting that none of the infant formula products tested in a five-state study "came close to meeting federal Vitamin D standards"); Product Recalls, NewSDAY, Nov. 14, 1990, at 47 (Nassau \& Suffolk ed.) (reporting recall of 26,000 cases of infant formula contaminated with bacteria).

205. See Breast Milk Chemical Fights Diarrhea in Infants, Reurers, May 6, 1992, available in LEXIS, Nexis Library, Wires File (mother's milk fights infectious diarrhea, which hospitalizes 200,000 infants and kills 500 infants every year in the United States); Health Groups Urge Worldwide Breast-Feeding, UPI, Mar. 9, 1992, available in LEXIS, Nexis Library, Wires File (breast-feeding infants, in lieu of using infant formula, could prevent over 1,000,000 deaths every year in the underdeveloped world by strengthening infant immune systems); Help Mothers Feed Their Babies, N.Y. TIMES, Oct. 12, 1991, at A28 (reporting findings that death and illness may be lower among breast-fed babies); Philip J. Hilts, Study Finds a Decline in Breast-Feeding, N.Y. Times, Oct. 3, 1991, at A12 (reporting a study's determination that breast-feeding helps babies' inmune systens and may lower sickness and death rates). 
ceived, ${ }^{206}$ consumers of infant formula may not incorporate them into their purchase decision. Attracted to an artificially low shelf price, they overconsume.

\section{Undertaxed}

The second characteristic of the market failure defense is that the product is not adequately taxed. Taxation is the traditional method of internalizing a negative externality. Taxation solves the problem of externality-induced overconsumption by increasing an artificially low shelf price to reflect the total price to society. Taxation is usually the preferred policy response to negative externalities because it can correct the market failure directly. To the extent that the specific amount of the externality per umit sold can be quantified, ${ }^{207}$ an excise tax can be set for this amount. Collusive pricing is anotlier method of producing the same results as taxation. Collusive pricing can move society toward the efficient equilibrium, as can taxation, but it is less precise. Despite this imprecision, collusive pricing may be tlie preferred solution for products that, for some reason, are undertaxed and resistant to furtlier taxation.

There are several reasons wlyy a particular product may be undertaxed and why collusive pricing may be necessary to attain a more efficient equilibrium. First, the political process may break down. Politics may make it difficult to impose new taxes or to form the legislative coalitions necessary to impose an excise tax on a particular product. It is often politically easier to tax monopoly profits at the corporate level rather than the product itself. For example, a tax on infant formula would be practically impossible to effect. Efficiency arguments aside, the public relations of imposing such a tax would be political suicide. ${ }^{208}$

Second, excise taxes are regressive. Some political factions may resist taxing individual products because sales taxes consume a greater percentage of a poor person's income thian a ricli person's, and therefore have a greater impact on lower-income consumers. Moreover, many products with higli negative externalities, such as gasoline, are disproportionally consumed by poor people. ${ }^{209}$ These demographic differences in

206. Lorrie Yoos, Developmental Issues and the Choice of Feeding Method of Adolescent Mothers, 14 J. ObSTETRIC GyNECOLIC \& NEONATAL NURSing 68, 68-72 (1985).

207. See Manning, supra note 202 (measuring externalities associated with smoking and drinking).

208. The corporate profits of firms that manufacture these goods can be taxed. For a discussion of monopoly profits, see infra Section IV.A.

209. J.P. STUCKeR \& T.F. KIRKWOOD, RAND CORP., THE ECONOMIC IMPACT OF AUTOMOBILE TRAVEL COST INCREASES ON HouseHolds (1979) (noting that the gasoline tax is regressive). Similarly, most woinen who use infant formula are poor. Of mothers with a family income less than $\$ 7,000,36.6 \%$ breast-feed, coinpared to over $70 \%$ in households with mcomes greater than \$25,000. See Allan Parachini, Breast-Feeding, Once on the Rise, Is Slowing, L.A. TIMES, Dec. 20, 1985, at V1. 
consumption increase the regressivity and the apparent unfairness of the system.

Even when taxes are imposed on a product, they must be high enough to internalize the externality; otherwise, there is overconsumption. For example, gasoline is taxed but the current federal and state taxes on gasoline do not approach the correct level needed for imternalization. ${ }^{210}$ As long as the externality is greater than the tax, increasing price enhances efficiency because it deters at least some of the overconsumption. In contrast to gasoline, some research suggests that tobacco's externalities are internalized by current taxes. ${ }^{211}$ However, if deterrence of adolescent smokers (who could become addicted and wish they had not started) is included as a consideration, the level of the efficient tax rises several fold. ${ }^{212}$ In this case, collusive prices move the market toward the efficient price (because a higher price deters some would-be sinokers) but the shelf price may still be too low. ${ }^{213}$ Thus, even though the collusive price inay not be the optimal price, eliminating horizontal price-fixing would decrease the shelf price and move society further away from the efficient equilibrium. ${ }^{214}$

\section{Elastic Demand}

The third characteristic necessary for a market failure defense is an elastic demand for the product. Elasticity measures how responsive consumers are to a change in price. If deinand is highly elastic, a small percentage change in price will cause a large percentage change in consumption. Demand for a good need not be perfectly elastic for the market failure defense to apply. So long as a price increase has some effect on demand, the price imcrease will cause consumption to drop, the externality will be internalized, and the market will be inore efficient. ${ }^{215}$ Gas-

210. Charles Komanoff, Steep Gas Tax Is One Way to Ease Fiscal Pain, Crain's N.Y. Bus., Sept. 30, 1991, at 12 (noting that, although current gas taxes are around 30 cents per gallon in the United States, the externalities exceed four dollars per gallon).

211. Manning, supra note 202, at 1608 (observing that estimated external cost of smoking, $\$ 0.15$ per pack, is less than average state and federal taxes, $\$ 0.37$ per pack).

212. See id. at 1608-09 (contending that fewer adolescents would become addicted to cigarettes if taxes on cigarettes were raised).

213. See id.

214. Id. at 1609 ("If the loss in life expectancy of 28 minutes per pack is relevant to economic efficiency because of later regret, an economically efficient tax would be on the order of $\$ 5$ per pack, the estimated value of the 28 minutes.").

215. The extent to which efficiency can be maximized in a negative externality context depends on the degree of demand elasticity. Even without elasticity, taxation might mitigate the harmful effects of products with negative externalities. Through taxation, government can raise the price of inelastic goods and thus generate a fund from which downstream costs can be paid. For example, the externalities of cigarettes might be internalized if the government directed tax revenue from cigarettes to health care facilities. However, compensation without a decrease in consumption is not as efficient as decreased consumption that obviates the need for compensation. In elastic markets, efficiency is maximized when consumption of "bad goods" is decreased, because the transaction 
oline is an example of a product that meets the requirement of price elasticity. Although in theory there is a minimum level of gas that an industrial society must use to sustain itself (and therefore, demand for gasoline becomes melastic at low quantities), over the relevant range of current consumption the demand for gasoline is elastic. ${ }^{216}$ As the price of gasoline rises, consumption falls.

In contrast, if deinand is inelastic, then consumers do not respond to a change in price. Thus, a market failure defense, which argues that increased price is necessary to curtail overconsumption, inay not apply to goods for which there is an inelastic deinand. Because price increases have no effect on the consumption of an inelastic good, collusive prices will not inaximize efficiency and the theory of the second best fails. This Section briefly discusses three products with inelastic deinand: addictive drugs, life-sustaining goods, and goods that are fully subsidized by others.

Addictive drugs have an inelastic demand because drug addicts are willing to pay any price for the product. So long as they are soinehow able to find the inoney, drug users will not decrease consuinption when the price of an addictive drug increases. For this reason, drug dealers soinetimes give drugs away and then begin charging for thein once drug users are addicted. ${ }^{217}$ Illicit drugs, of course, are outside the scope of antitrust. However, inany legal products, such as over-the-counter and prescription drugs, are addictive. Cigarettes also are addictive and sinokers usually will not conform their consumption according to the price of cigarettes. ${ }^{218}$

Like addictive drugs, life-sustaining drugs also have an inelastic deinand and, thus, consumers of such drugs will ignore price changes. For exainple, the deinand for insulin by diabetics does not decrease if the price of insulin increases. ${ }^{219}$ However, it is difficult to conceive of lifesustaining goods with negative externalities for which it would be efficient, let alone ethical, to allow severe price increases.

Similarly, deinand for products that are fully subsidized by a third party are inelastic. If the "purchaser" does not actually pay for the prod-

costs of compensation are avoided. These transaction costs can be significant, as in the costly litigation related to compensation of asbestos victims.

216. Gerald C. Meyers, Blame Consumers for Gas-Guzzling Cars, L.A. TiMES, Sept. 9, 1990, at D9.

217. See Michael Marriott, Addicts Awaiting Treatment Often Face Delays and Panic, N.Y. Times, Jan. 10, 1990, at A1.

218. See Liggett Group, Inc. v. Brown \& Williamson Tobacco Corp., 748 F. Supp. 344, 353 \& n.27 (M.D.N.C. 1990) (noting an economist's opinion that demand for cigarettes is inelastic), aff'd, 964 F.2d 335 (4th Cir. 1992); John Peterson, No Drought Seen in Revenue Figures, UP1, Aug. 3, 1988, available in LEXIS, Nexis Library, Wires File (noting an increase in cigarette sales despite a $10 \%$ increase in cigarette taxes).

219. Geoffrey A. Campbell, Higher Excise Taxes Would Hit State Finances, Lawmakers Conference Warns in New Report, BOND BuYER, Sept. 18, 1990, at 2. 
uct, he may not see or care about its price, and therefore not respond to changes in that price. For example, many consumers do not actually pay the shelf price for infant formula. Under the federal government's Special Supplemental Food Program for Women, Infants and Children (WIC), mothers use vouchers provided by the government to purchase infant formula. ${ }^{220}$ Consumers who use vouchers need not ever look at the shelf price. For these products and consumers, collusion that mcreases price cannot internalize the externality because the consumers pay no attention to the price; consumption remains inefficient.

\section{Availability of Feasible Alternatives}

The fourth characteristic of the market failure defense is the existence of feasible alternatives to the product. If there are no adequate substitutes, consumers and society may be worse off when prices rise. Some goods which have negative externalities have no appropriate substitutes. For example, in the case of infant formula: the externality is internatized when mothers shift to breast-feeding. Breast-feeding seems like an ideal alternative to infant formula: it's healthier, ${ }^{221}$ relatively convenient, and free. Unfortunately, for some mothers, breast-feeding is not an alternative to formula. Some new mothers cannot lactate and therefore must use infant formula. Some women are biologically incapable of breastfeeding; others imcorrectly believe that they cannot breast-feed. ${ }^{222}$ Finally, some new mothers, especially adolescent mothers, have been socialized not to breast-feed their newborn babies. ${ }^{223}$ For these women there is no feasible alternative to infant formula, because available options may be far worse. For example, as an alternative some mothers may simply buy less and dilute the formula so that it lasts longer. Thus, while infants would receive the same amount of liquid, they would receive fewer nutrients. Improper preparation and dilution of infant formula can contribute to infant death. ${ }^{224} \mathrm{Or}$, some mothers may shift to even worse alternatives. In some countries, mothers have substituted cola, coffee, and cow's milk for infant formula when the price of infant formula has increased or the supply has declined. ${ }^{225}$ Therefore, noncon-

220. Gideon Forman, Cutting WIC, NATion, July 9, 1990, at 57.

221. Hilts, supra note 205.

222. Donelda J. Ellis, Secondary School Students' Attitudes and Beliefs About Breastfeeding, 53 J. SCH. HEALTH 600, 602 (1983).

223. See Anna Berger \& S.T. Winter, Attitudes and Knowledge of Secondary School Girls Concerning Breastfeeding, 19 CliniCAL PEDIATRICs 825, 826 (1990); Regina M. Cusson, Attitudes Toward Breast-Feeding Among Female High-School Students, 11 PEDIATRIC NuRsing 189-91 (1985) (concluding that adolescents with exposure to breast-feeding in the home are more likely to have positive attitudes toward breast-feeding).

224. Michelle Faul, Improper Formula Feeding Spreads Malnutrition, Death in Third World, L.A. TIMES, May 19, 1991, at A.3 (describing severe and sometimes fatal health effects of infant formula use in third-world conditions).

225. See, e.g., Carolyn Adolph, Cow's Milk Takes Toll on Babies of the Poor, GazETTE 
sumption of a good with a negative externality may increase societal costs. This happens when women who cannot afford to pay the collusive price $^{226}$ are unable or unwilling to breast-feed.

Most goods have appropriate alternatives. Gasoline has several feasible alternatives. First, for soine uses, cleaner energy sources, such as solar power, co-generation, and wind power, can be substituted for gasoline. Second, the alternative may simply be less consumption. ${ }^{227}$ Conservation of gasoline decreases the negative externality without imposing additional costs. Conservation can be seen as a sectoral shift. Third, the alternative need not be a substitute for the good itself but can be a shift in a complementary good. In the case of gasoline, the "alternative" may be more fuel-efficient cars. ${ }^{228}$ As gasoline prices rise, people shift to automobiles that use less gas. ${ }^{229}$

As shelf price (or in this case, pump price) reflects total societal cost, including production and environmental costs, consumers adjust their consuinption patterns to the efficient equilibrium. Empirically, as gasoline prices rise, alternatives becoine relatively cost-efficient. In other words, an artificially low price for gasoline discourages productive investinent in alternative energy sectors of the econoiny. Price collusion in gasoline inay inake investment in alternative energy sources more profitable and provide more accurate relative rates of return.

\section{B. Reflections on the Case Studies}

Gasoline, tobacco, and infant formula were not chosen for this discussion because they each satisfy all four eleinents of the inarket failure defense, but because they illustrate different types of externalities and varying levels of taxability, elasticity, and substitutability. Gasoline comes the closest to satisfying all four requireinents. It has well-documented environmental externalities, as well as deinand elasticity and substitutability. When the price of gasoline rises, people consuine less, either by conserving or by shifting to alternative energy sources. This drop in consumption increases efficiency. Gasoline is taxed and probably could be taxed inore, but it is doubtful that a pohtical coalition could be formed

(Montreal), Aug. 3, 1992, at A1, available in LEXIS, Nexis Library, Currnt File (noting that when infant formula is not available soine inothers shift to cow's milk, which is low in iron).

226. Although WIC provides infant formula for many unothers, inany women fall through the cracks. WIC only reaches one-half to two-thirds of those eligible. Stefan Harvey, Women and Children Need More Help, USA TodAY, Aug. 14, 1990, at A8, available in LEXIS, Nexis Library, Currnt File.

227. Obviously, in the case of infant formula, decreased consumption without product substitution is dangerous.

228. STUCKER \& KIRKwOOD, supra note 209, at 53.

229. Meyers, supra note 216 , at D9. This shift to more fuel-efficient cars is a variant of decreased consumption, but is distinct to the extent that utility, as measured in miles traveled, is not affected. 
which would tax gasoline enough to internalize the entire externality. Thus, gasoline is a good candidate for inarket failure defense protection.

Tobacco is a less clear case. Cigarettes have significant negative externalities, and the elasticity and substitutability requireinents are met by einpirical data showing that, overall, consumers respond to increases in price with decreased consumption. However, current taxes already may be sufficiently high to deter new consumption of cigarettes.

Infant formula is the best example of a product that is not now taxed and would be resistant to new taxes. Nevertheless, infant formula is not a good candidate for market failure defense protection because there is no demand elasticity for those inothers whose use of formula is subsidized by WIC. ${ }^{230}$ Moreover, for those mothers who personally pay for their own formula, price-fixing may have a perverse effect on consumption, actually increasing externalities. While some inothers may respond to an imcrease in price by breast-feeding, others inay respond by using harmful substitutes, such as diluted formula or cow's milk.

In sum, all three products illustrate at least one form of negative externality. Also, in terms of taxability, each product demonstrates a different type of response to new taxes: taxation of infant formula raises the specter of unacceptable new externalities; political realities make it unlikely that gasoline could ever be taxed enough to internalize all its externalities; and tobacco may already be taxed enough to internalize its negative externalities and deter new consumption. As for elasticity, each product represents a different degree: gasoline is relatively elastic, tobacco moderately elastic, and infant formula relatively inelastic. Finally, each product has a different range of feasible alternatives. For both gasoline and tobacco, less consumption is a reasonable alternative. For infant formula, however, reduced consumption may prove dangerous, because there is no guarantee that mothers will switch to a reasonable alternative.

\section{IV}

\section{Putting the Theory of The Second Best into OPERATION}

\section{A. Windfall Profits}

Allowing a market failure defense in price-fixing cases creates the opportumity for monopoly profits. For example, the governinent creates inonopoly profits whenever it grants a patent or copyright. This is seen as unobjectionable because these short-term excess profits reward previous investment and innovation. However, any excess profits obtained through price-fixing and a successful inarket failure defense are viewed as

230. See supra text accompanying note 220 . 
windfall profits because they are earned not by productive activity but by otherwise illegal conduct which happens to be efficient.

There are two related issues with respect to windfall profits: wealth transfer and ill-gotten gains. ${ }^{231}$ In some cases, permitting firms to collude and increase the price of products with high negative externalities transfers wealth from consumers to business. These wealth transfers occur in two ways. First, some consumers are excluded from the market as supply and consumption decrease. Second, those consumers who remain in the inarket must pay more for each unit. To the extent that antitrust is concerned with preventing these types of wealth transfers, the market failure defense is resisted on equity grounds.

In the context of products with negative externalities, however, wealth transfers are an illusory problem. Traditionally, wealth transfers are disfavored because firms increase producer surplus at the expense of consumer surplus. However, charging higher prices for products with negative externalities does not cause a traditional kind of lost consunier surplus. Although consumer surplus exists when the willingness to pay (as shown by the demand curve) is greater than price, this usually assumes that both demand and price are above cost. When there is a negative externality, price is lower than the actual total societal cost. The marginal consumer does not value the good more than it costs society to produce it. Indeed, consumers as a whole actually benefit from higher prices because resources are shifted to beneficial sectors of the economy. ${ }^{232}$

The goal of internalizing negative externalities is not to price gouge; it is to eliminate mefficient overconsumption by the marginal consumer. The resources that would have gone into making products with high negative externalities will be invested in products where consumers value each unit more than its cost. Thus, in the long run the efficiency standard protects consumers' interests. By maximizimg efficiency, the market failure defense maximizes consumer welfare. The traditional disdain of wealth transfers is misplaced in inarkets with multiple failures.

That is not to deny that disgorging windfall profits from collusive pricing is a legitimate goal. In fact, several members of Congress and the judiciary view disgorging ill-gotten gains as an important objective

231. A third problem caused by windfall profits is rent-seeking. Whenever the government grants a monopoly and creates the opportunity for monopoly profits, individuals will compete for the right to possess the monopoly and reap those profits. Individuals will spend resources lobbying and jockeying for position. This rent-seeking behavior is inefficient because resources are allocated to activity which has no productive utility. Competing for monopoly profits does not make the "pie" bigger. It merely determines who gets what slice. Admittedly, by creating the opportunity for monopoly profits a market failure defense could encourage rent-seeking. For a fuller discussion of this problem, see Richard A. Posner, The Social Costs of Monopoly and Regulation, in TOWARD A THEORY OF THE RENT-SEEKING SociETY 71, 71-94 (James M. Buchanan et al. eds., 1980).

232. See supra notes $175-77$ and accompanying text. 
of antitrust laws. ${ }^{233}$ For example, the Hart-Scott-Rodino Antitrust Inprovements Act of $1976^{234}$ added new parens patriae provisions which allow state attorneys general to coinpel violators to disgorge ill-gained profits by brimging suit on behalf of consumers under the Sherman Act. ${ }^{235}$

Perhaps the strongest argument agamst allowing a inarket failure defense for products with high negative externalities is that allowing price collusion rewards corporations with a higher rate of return simply because they produce and/or sell a product with downstreain costs. The view is that antitrust law should not establish an incentive system where a higher rate of return encourages entrepreneurs to invest in industries with higher negative externalities. ${ }^{236}$ Defendants receiving such a return are seen as not having "earned" the profits. Solne would view the defendant's collusive pricing as two independent wrongs: collusion and production of downstream costs. Allowing excessive profits froin such collusive pricing seems, solnehow, unfair.

However, even within a framework that accepts the inarket failure defense, the government can address the problem of windfall profits in at least two ways. First, the government can tax monopoly profits. This taxation is distinct from a traditional excise tax in that the consumer never actually sees the tax added on to the base price, although the net effect of a scheme that accepts a market failure defense and taxes unearned profits inay be a higher retail price. The government can apply this monopoly profits tax in a variety of ways. In the case of gasoline, for example, the government may either tax windfall profits directly or inay direct the profits to inore beneficial sectors of the economy through tax credits. Thus, oil compames might be given tax credits to reinvest in alteruative energy sources.

Second, the government can simply ignore the windfall. Although it might seem unfair, there is still a comparative advantage to allowing the collusion even if suppliers retain windfall profits. The advantage lies in the efficiency derived from preventing overconsuinption. It would be inefficient to proinote overconsumption simply to prevent companies from receiving "excess" profits. While there is nothimg inlierently inefficient or unethical about windfall profits, there is something inherently detrimental about allocative inefficiency: overconsumption shifts resources to one sector of the economy when those resources would be better spent in another sector. The government sliould not, in "punish-

233. See United States v. Aluninun Co. of Am., 148 F.2d 416, 428-29 (2d Cir. 1945) (citing statenents by legislators and one Suprenie Court Justice to the effect that one purpose of antitrust is to avoid wealth consolidation).

234. Pub. L. No. 94-435, 90 Stat. 1383 (codified as anrended in scattered sections of 15 U.S.C.).

235. 15 U.S.C. § 15(c)-(g) (Supp. III 1991).

236. Arguably, this counterproductive incentive structure is inost effectively remedied by taxing inonopoly profits. 
ing" the corporation, impose unnecessary costs on society through the misallocation of scarce resources. Likewise, antitrust law should not misallocate scarce resources because of reflexive hostility to collusive pricing. Granted, in inost cases collusion does misallocate resources through increased price and decreased quantity. Naturally, antitrust law should operate with an eye toward correcting this evil. However, when the collusion involves products with negative externalities, collusion inay actually enhance resource allocation. Society should focus more on encouraging allocative efficiency and less on eliminating windfall profits.

Finally, windfall profits in reality may be no "windfall" at all to the corporation. Research suggests that windfall profits from price-fixing inay be neghigible. ${ }^{237}$ One explanation is that producer surplus is invested in risk-taking ventures, new product development, and other innovations. ${ }^{238}$ Therefore, monopoly and windfall profits inay have beneficial econoiny-wide effects by increasing research and development, innovation, and philanthropy. Moreover, windfall profits do not arise solely froin collusion but are a function of the original market failurethe negative externality. The possibility of windfall profits exists whenever price hikes internalize a negative externality. As one commentator explained, "Whenever social cost exceeds private cost, forcing price soinehow to reflect social cost generates the possibility of a inonopoly profit."239 Therefore, the inarket failure defense does not create additional problems so much as it inakes the best of existing failures.

\section{B. Uncertainty}

In general, commentators and judges are officially reluctant to alter antitrust doctrine. ${ }^{240} \mathrm{~A}$ shift in antitrust rules, away from per se rules and toward allowing the inarket failure defense, could intensify business uncertainty, distorting business conduct and increasing administrative costs. ${ }^{241}$ Uncertainty in the inarketplace can cause a chilling effect on corporate America. If business is unclear about the current state of antitrust law, it is difficult to adjust business practices in order to insure compliance. Due in part to the specter of treble damages, business may be overly cautious in the face of uncertainty. For exainple, what confidence can a firm have that its level of collusion is efficient? Aversion to risk, induced by the uncertain climate, nnay skew business decisions and deter beneficial conduct. This uncertainty is supposed to be elimmated by bright line tests, such as the per se rules. Bright line rules in the antitrust

237. McChesney, supra note 162 , at 360 .

238. See Rule \& Meyer, supra note 54, at 684-86.

239. Lopatka, supra note 184, at 59.

240. See, e.g., United States v. Topco Assocs., Inc., 405 U.S. 596, 609-12 (1972) (emphasizing that Congress is better equipped than the Court to modify antitrust law).

241. Donald I. Baker \& William Blumenthal, Ideological Cycles and Unstable Antitrust Rules, 31 ANTTTRUST Bull. 323, 334-35 (1986). 
field are valued because "[t]heir clarity guides conduct, simplifies planning, minimizes conflict, reduces resort to the courts, simplifies the conduct of hitigation, allows juries and judges to reach confident and consistent results, and promotes justice in the sense of similar treatment for those similarly situated."242

Admittedly, allowing a market failure defense would diminish the advantages of bright line rules by increasing uncertainty. Yet the benefits of allowing second best analysis outweigh whatever administrative and uncertainty costs it might entail. First, bright line tests are not a panacea in antitrust. In cutting through gray areas, bright line rules necessarily entail some over- and underinclusion. ${ }^{243}$ Efficient behavior is inevitably deterred and sometimes punished. Bright line tests are merely rules of convenience which remove judges' discretion. ${ }^{244}$ Moreover, while hine drawing is difficult and complex, courts engage in balancing all the time; that is what judges are supposed to do.

Second, antitrust is constantly changing. Changes in ideological positions on the proper goals and focus of antitrust laws already create business uncertainty. ${ }^{245}$ Congressman Rodino, co-author of the HartScott-Rodino gindelines, observed that "[o]n an almost daily basis, there are new judicial interpretations, antitrust guidelines issued by federal and state authorities, and evolving economic and legal analyses."246 Restraints once deemed per se violations are increasingly considered under the rule of reason. ${ }^{247}$ If antitrust law were static, strict maintenance of per se rules might make sense; however, antitrust is dynanic. A shift to a more efficient rule should not be tabled in the name of contriuity.

Third, these uncertaimty arguments indict the foundation of the rule of reason. Problems of business predictability inevitably exist in cases where the rule of reason is apphed, yet the majority of antitrust violations are adjudicated under the rule of reason. ${ }^{248}$ What constitutes "reasonable" behavior is not clear in any given situation. Yet the lack of clarity in deciding what is "reasonable" is somehow managed by industry and the courts. ${ }^{249}$ Courts uphold vertical price-fixing arrangements in some

242. Areeda, supra note 103, at 42 .

243. Id. at 43.

244. Id.

245. Baker \& Blumenthal, supra note 241, at 324.

246. Rodino, supra note 55 , at 588 .

247. See supra text accompanying notes 29-37.

248. Continental T.V., Inc. v. GTE Sylvania, Inc., 433 U.S. 36, 59 (1977).

249. Discussing the imherent uncertainty of antitrust law, the Supreme Court in Nash v. United States, 229 U.S. 373, 377 (1913), noted that "the law is full of instances where a man's fate depends on his estimating rightly." 
case $^{250}$ and in other cases strike them down as "unreasonable."251 Business adapts and operates smoothly in the face of this uncertainty; it can handle one inore form of uncertainty. ${ }^{252}$

Fourth, because the definition of price-fixing is in flux, even the current per se rules offer no real guidance to business. It is not now clear when a price restraint is "naked" or "ancillary," and what level of scrutiny the court will apply to it. ${ }^{253}$ If firms are uncertain whether conduct constitutes price-fixing, they cannot order their business affairs to conform to the Sherman Act. A inarket failure defense, at its worst, adds another wrinkle to an already rumpled state of law.

\section{Incentives to Argue the Market Failure Defense}

One important question at the trial level is who would have the incentive to imitiate inarket failure arguments. Defendant firms could argue that negative externalities justify any alleged collusion. The defendant is in control of the best information on costs and effects, data that is necessary to determine the efficient level of consumption. The defendant also has an incentive to present data on negative externalities in order to avoid treble damages. However, if the incentive is too large, all firms may consider claiming the existence of a negative externality, even when one does not in fact exist. Some might argue that firms have an incentive to invent or create negative externalities. However, the intentional creation of externalities would be irrational and unlikely considering the possibilities of unnecessary tort hability and adverse publicity.

If they were allowed to, and chose to, argue the market failure defense, defendants might risk tort liability and adverse publicity despite not having intentionally created negative externalities. In arguing the inarket failure defense, defendants would have to show that their products had negative externalities. In some cases, the negative externahty is well known and the industry does not experience a loss by merely admitting its existence. For example, it is no secret that fossil fuels release carbon dioxide. The petroleuin industry loses no ground admitting the externality and using it to justify any alleged collusion. On the other hand, in other cases the defendant could risk embarassment in the public

250. See, e.g., Business Elecs. Corp. v. Sharp Elecs. Corp., 485 U.S. 717 (1988) (holding that a vertical restraint is not per se illegal unless it includes some agreement of price or price levels).

251. See Urited States v. Arnold Schwinn \& Co., 388 U.S. 365, $377-79$ (1967), overruled by Continental T.V., 433 U.S. at 59.

252. Of course, there are many different types of uncertainty. Businesses may be uncertain about future deinand, their input sources, and the "reasonableness" of suspect conduct. A market failure defense would introduce a new uncertainty, namely, whether a fixed price merely internalized an externality or was inefficiently high. Firms that collude could adjust to this brand of uncertainty by being conservative and raising prices only to imternalize sufficiently quantifiable external costs.

253. McChesney, supra note 162 , at 369. 
eye or tort liability. The opportunity to retain nonopoly profits could compel a defendant to swallow these risks and argue the market failure defense. ${ }^{254}$ Granted, because of the different risks, it may not be clear whether a defendant will choose to argue the market failure defense. However, this uncertainty is irrelevant to whether the defense should be available to those defendants who choose to argue it. ${ }^{255}$

Finally, the theory of the second best may be adopted by the governnent itself. By recognizing that second best pricing can maximize efficiency, the Federal Trade Commission and Departnent of Justice, relynig on their prosecutorial discretion, may simply forego prosecutions against products with high negative externalities. These prosecutors may then target their scarce resources to cases where price-fixing is inefficient and simply gouges consumers, with no redeeming effects. Many private antitrust claims ride on the coattails of government lawsuits. ${ }^{256}$ Even unsuccessful government suits can create follow-on private litigation. If the federal government acknowledged the market failure defense, there would be fewer government actions and fewer of these follow-on suits. If the Departinent of Justice and Federal Trade Commission decline to litigate cases against applicable price-fixing arrangenıents, the theory of the second best will more or less be successfully impleinented and antitrust can again be a tool to inaximize efficiency. By considering second best theory froin the start, the executive brancli can nıaximize allocative efficiency witl no expenditure of judicial resources.

\section{Determining Efficient Equilibria and Reasonable Prices at Trial}

To evaluate a nrarket failure defense at trial, the finder of fact nuust determine what the efficient equilibrium is and whetlier the horizontal price-fixing puslies the inarket closer to this equilibrium. To determine the efficient equilibrium in the absence of all niarket failures, one only needs to derive the supply and dentand curves. The supply curve is a function of costs which are routinely determined in other antitrust contexts, sucl as in predatory pricing cases. Deriving demand curves is cominon fare in economics.

In other contexts, the Supreme Court lias avoided what it considers complex economic theories. ${ }^{257}$ In general, it may be difficult to deter-

254. See Lopatka, supra note 184 , at 60 (" $[\mathrm{B}]$ ecause efficiency may be enhanced by permitting a supplier to earn a monopoly profit, it would not be surprising if a supplier brought to the [government's] attention a proposed solution to the problem of external costs that would produce a benefit for himself.").

255. Amicus briefs may also argue negative externalities. Environmentalists may want to argue that externalities justify pricing that deters increased consumption, as they have argued in regard to gas taxes. Journeymen economists as well may wish to participate regarding externalities.

256. For example, after the FTC announced its investigation into infant formula price-fixing, retailers filed antitrust claims against infant formula manufacturers.

257. See Hanover Shoe, Inc. v. United Shoe Machinery Corp., 392 U.S. 481, $491-94$ (1988) 
mine whether a price is reasonable. Such calculations "require a continuous monitoring of prices and the repeated, excruciatingly difficult determination of whether an unreasonable elevation ha[s] occurred."258 These difficulties have led some commentators to worry that the courts are ill-equipped to measure externalities. ${ }^{259}$ Likewise, in justifying its reluctance to officially apply the rule of reason to horizontal price-fixing, the Court has questioned the judiciary's expertise in economic matters. In both horizontal and vertical contexts, the Court has claimed that Congress "can, of course, make per se rules inapplicable in some or all cases, and leave courts frce to ramble through the wilds of economic theory in order to nuaintain a flexible approach.",260

The Court's modesty is misplaced. The judiciary has quantified or weighed efficiencies in many contexts. ${ }^{261}$ In addition to discussing and applying economic theory and data in rule of reason cases, the Court has analyzed several other coinplex economic issues: the probability of success of a predatory pricing scheme, vertical price-fixing, market structures, productive efficiencies, market share, and market power. Measuring efficiencies in the merger context is also extremely difficult. ${ }^{262}$ Nonetheless, the courts accept these efficiency arguments without elaborate discussion. The market failure defense would present courts with just one more economic theory and its application to one type of conduct. The Court should not ignore economic theory simply because the theory is inessy. ${ }^{263}$ Given the Court's constant excursions into economic analysis regarding several categories of trade restraints, it is disingenuous for the Court to claim that horizontal price-fixing is too complex.

After Broadcast Music and NCAA, the courts began engaging in extensive economic analysis even when applying the per se rule to horizontal price-fixing. The Court admitted in NCAA: "Indeed, there is often no bright line separating per se from Rule of Reason analysis. Per se rules may require considerable inquiry into market conditions before

(declining to entertain defendants' complex, theoretical "passing-on" defense because of difficulties in applying it to the rcal world).

258. David B. Audretsch, Divergent Views in Antitrust Economics, 33 ANTrTrust Bull. 135, 148 (1988) (quoting F.M. Scherer, The Posnerian Harvest: Separating the Wheat from Chaff, 86 YALE L.J. 974, 984 (1977) (reviewing Richard A. POSNER, ANTITRUST LAW: AN ECONOMIC PERSPECTIVE (1976))).

259. Even Judge Bork, who argues that externalities are relevant, believes that action should be taken by the legislature rather than the judiciary. See BoRK, supra note 49, at 114-15 (arguing that externality and second best calculations exceed judicial competence). This view seems impractical considering that the legislature cannot act on a case-by-case basis, as can the courts.

260. Arizona v. Maricopa County Medical Soc'y, 457 U.S. 332, 335 n.30 (quoting Urited States

v. Topco Assocs., Inc., 405 U.S. 596, 610 n.10 (1972)).

261. See supra Section I.C.3.c.ii.

262. Richard A. Posner, ANtTtrust LaW: AN Economic Perspective 112 (1976).

263. See Maple Flooring Mfrs.' Ass'n v. United States, 268 U.S. 563, 584 (1925) ('[T]he Shernnan Law neither repeals economic laws nor prohibits the gathering and dissemination of information."). 
the evidence justifies a presumption of anticompetitive conduct."264 If the goal of per se rules is to avoid discussion of economic efficiencies, it has failed. In fact, in all of the price-fixing cases of the 1980 s the Supreine Court went to great lengths to explain why the per se behavior was anticoinpetitive, discussing extensively its economic and coinpetitive effects. ${ }^{265}$ Thus, per se rules in reality have not achieved their intended effect of simplifying the analysis.

Moreover, while analyzing allocative efficiency in horizontal pricefixing cases inay be difficult, the Court has exainined productive efficiency before in other contexts. The related task of quantifying allocative inefficiencies is not substantially different. If anything, determining allocative efficiency may be easier than analyzing productive efficiency because the allocative efficiency question has an objectively correct answer, the equilibriuin point where marginal cost equals inarginal revenue. The Court forgets that antitrust law and its apphication are inherently coinplex. Complexity of analysis alone is not a sufficient justification to leave allocative efficiencies unexamined.

One resource available to trial courts for determining efficient prices is expert witness testimony. Economists already frequently testify about inarket efficiency, market structure, economic theory, and the effects of price-fixing. ${ }^{266}$ Similar testimony can be used at trial in cases where a market failure defense is invoked, because the externalities of products can be quantified. ${ }^{267}$ The efficiency standard, which would guide courts in cases involving the market failure defense, is useful because it can be "calibrated in dollars," an "objectively verifiable standard."268

Rules and procedures are already in place to handle the inherent coinplexity of antitrust. Many courts now allow expert testimony on ultimate facts, ${ }^{269}$ which in the case of the inarket failure defense would include the allocative efficiency of a given price. Moreover, issues of antitrust experts' qualifications are easily handled through the Federal Rules of Evidence. ${ }^{270}$ The court may permit parties to subpoena unretained experts. ${ }^{271}$ If the court is not satisfied with the testinony of the parties' witnesses, Federal Rule of Evidence 706(a) authorizes the court to

264. NCAA v. Board of Regents of the Univ. of Okla., 468 U.S. 85, 104 n.26 (1984).

265. See supra text accompanying notes 113-62.

266. ABA ANTITRUst LAW SEction, ANTITRUST EVIDENCE HANDBooK 117-20 (1991).

267. See Manning, supra note 202, at 1604 (measuring externalities associated with smoking and drinking).

268. Rule \& Meyer, supra note 54, at 694.

269. ABA ANTITRUSt LAW SEction, supra note 266, at 125-26 (citing In re Japanese Elec. Prods. Antitrust Litig., 723 F.2d 238, 278 (3d Cir. 1983); 3 JACK B. WeInsteIn \& Margaret A. BERGER, WEINSTEIN'S EVIDENCE I] 704[02] (1988)); see also FED. R. Evid. 704.

270. See ABA ANTITRUst LAw SEction, supra note 266, at 127-28 (noting that FED. R. EVID. 104(a) makes qualifications a preliminary question subject to court's discretion).

271. Id. at 132 (citing Kaufman v. Edelstein, 539 F.2d 811, 822 (2d Cir. 1976)). 
appoint expert economic witnesses sua sponte. ${ }^{272}$ A court may even use an economics or antitrust expert as a consultant or advisor without requiring the expert to testify. ${ }^{273}$ While economists frequently disagree with each other, and both parties to a dispute would take advantage of that fact, disagreement among experts would not present an atypical probleın; judges and juries frequently are asked to evaluate competing testimony.

In addition to evaluating competing testimony, juries would be asked to evaluate inarket failure arguments in their entirety. Placing this responsibility on juries would not present an insurmountable problein. First, inost coinplex antitrust suits are settled by summary judgment. ${ }^{274}$ Second, even if a case goes to jury, jurics must analyze comphicated eeonomic data in other antitrust cases that imvolve the rule of reason. Third, experts can (and do) present eeonomic theory and data to juries im ways that facilitate intelligent decisionmaking. Demonstrative evidence, such as charts, graphs, and glossaries, can be used to explam both economic theory and existing facts. ${ }^{275}$

\section{$\mathrm{V}$ \\ CONCLUSION}

The objective of antitrust law is to maximize allocative efficiency. In a free inarket, the invisible hand achieves this goal. Sometimes the invisible hand fails. When it does, regulations, hability, and antitrust law are necessary to achieve the efficient equilibrium. But when the hand is not broken, it should not be put in a cast. Colluding businesses, operating only in their own self-interest, can maximize allocative efficiency. Antitrust law should not interfere with this result.

The Supreme Court's rationale for precluding a market failure defense is no longer valid. Antitrust law has evolved to a point where efficiency is routimely discussed. The development of economic theory and the growing sophistication of the judiciary warrant change; what was once prudent judicial decisioumaking is now overly cautious and counterproductive. Because efficiency is the goal of antitrust, efficiency should be the decision variable employed by the courts. There is no need to rely on competition as a proxy. With current economic tools and

272. Id. at 130. Under FED. R. EviD. 706(b), the parties inust compensate court-appointed witnesses. ABA ANTITRUST LAW SECTION, supra note 266, at 131-32.

273. See Reilly v. United States, 863 F.2d 149, 154-59 (1st Cir. 1988) (upholding the district court's exercise of discretion in appointing technical expert to assist court in understanding econonic theory).

274. See, e.g., Eastman Kodak Co. v. Inrage Technical Servs., 112 S. Ct. 2072, 2076 (1992) (involving "yet another case that concerns the standard for summary judgment in an antitrust controversy"); Matsushita Elec. Indus. Co. v. Zenith Radio Corp., 475 U.S. 574 (1985) (addressing cases on appeal resolved below on summary judgment).

275. ABA ANTtTrust Law Section, supra note 266, at 135-36. 
understanding, courts can evaluate efficiency directly. They do so in most antitrust contexts. They should do so in the context of horizontal price-fixing. 